Article

\title{
Sustainability in Brandenburg Study Programs. Perspectives for Anchoring Sustainability in Higher Education Curricula
}

\author{
Jennifer Maria Krah *, Julian Reimann and Heike Molitor
}

check for

updates

Citation: Krah, J.M.; Reimann, J.;

Molitor, H. Sustainability in

Brandenburg Study Programs.

Perspectives for Anchoring

Sustainability in Higher Education

Curricula. Sustainability 2021, 13, 3958

https://doi.org/10.3390/su13073958

Academic Editors: Daniel Schiller,

Verena Radinger-Peer and Marc

A. Rosen

Received: 28 December 2020

Accepted: 19 March 2021

Published: 2 April 2021

Publisher's Note: MDPI stays neutral with regard to jurisdictional claims in published maps and institutional affiliations.

Copyright: (c) 2021 by the authors. Licensee MDPI, Basel, Switzerland. This article is an open access article distributed under the terms and conditions of the Creative Commons Attribution (CC BY) license (https:/ / creativecommons.org/licenses/by/ $4.0 /)$.
Faculty of Landscape Management and Nature Conservation, Eberswalde University for Sustainable Development, 16225 Eberswalde, Germany; Julian.Reimann@hnee.de (J.R.); Heike.Molitor@hnee.de (H.M.)

* Correspondence: Jennifer.Krah@hnee.de

Abstract: The study investigates the extent to which sustainability is anchored in university curricula of a federal state (Brandenburg, Germany). (1) It provides a baseline for identifying opportunities for sustainability-related curriculum reform by analyzing study programs, levels and type of degree, level of anchoring, and context within the documents. (2) The case studies included an analysis and quantitative evaluation of 748 curricular documents. (3) A third of the study programs refer to sustainability; to an equal extent in both bachelor's and master's programs, and to an above-average extent in the fields of science and engineering. There is a strong commitment to sustainability in $12 \%$ of the curricula; however, it is strongly anchored in only $3 \%$ of study and examination regulations, and in only $9 \%$ of module descriptions. (4) For the first time, we have comprehensive results on sustainability in university curricula of an entire federal state and can discuss potentials for its further integration. The innovative method was developed out of the National Monitoring on Education for Sustainable Development (ESD) and adapted to the federal state level; the analysis of curricula through a wider set of variables is transferrable to other states. (5) The study provides indications for the regional development of universities which is crucial for future regional sustainability transformation.

Keywords: higher education; sustainability; transformation; curricula; sustainability courses; education for sustainable development (ESD); education policy; governance; regional development; monitoring and evaluation; document analysis

\section{Introduction}

\subsection{Anchoring Sustainability in Higher Education Curricula}

Both the updated version of the 2019 Sustainability Strategy and the Higher Education Contracts (2019-2023) for the state of Brandenburg pursue the goal of the comprehensive anchoring of Education for Sustainable Development (ESD) in higher education [1,2]. Plans include the "Implementation of ESD into (existing) curricula" [1], and there are also recommendations for introducing interdisciplinary and transdisciplinary introductory modules on the subject of ESD/Sustainability" [2]. Education for Sustainable Development is an integral component of high-quality education for all areas "that enhances cognitive, social and emotional and behavioral dimensions of learning" [3] (p. 8). It represents a holistic and transformative approach. "ESD is recognized as a key enabler of all SDGs and achieves its purpose by transforming society" [3] (p. 8). Sustainable Development Goal (SDG) 4 on Quality Education/Education for Sustainable Development is considered to be a central leverage point for societal transformation towards sustainable development [4]. If this is the case, the curricula of study programs in (higher) education become a success factor in sustainable development itself.

The university political discourse on the subject of sustainability, or Education for Sustainable Development, is shaped by international agreements, in particular the adoption of the Sustainable Development Goals by the United Nations in 2015 in New York [5]. Of 
similar importance for the education system was the UNESCO Global Action Program on Education for Sustainable Development (2015-2019) which was put into concrete terms for Germany in the National Action Plan for the implementation of the Global Action Program [6]. A forum of experts was set up, explicitly devoted to the area of higher education which called for the structural anchoring of ESD in the country's laws and regulations. As the representative body of all the German universities, the German Rectors' Conference (Hochschulrektorenkonferenz, HRK) issued a recommendation in 2018 in which it called for sustainability to be a firm goal for Germany's universities [7]. At a state-level, there are also initiatives to promote sustainable development in universities, as is shown by the networks in Bavaria, Baden-Württemberg, and Brandenburg which strengthen the framework conditions for more sustainability in research, teaching, transfer, governance, and operation of the universities. The Global Action Program for ESD continues in the UNESCO framework "Education for Sustainable Development: Towards achieving the SDGs" (2020-2030) [8].

Finding space in the curricula for sustainability is considered a key condition for success in the implementation and institutionalization of ESD in higher education. Anchoring sustainability within the university system however presents a challenge [9-11], see also [12-14]: "While we have some understanding of the ways in which Higher Education Institutions (HEIs) bring in significant changes, such as for ESD, we have little evidence of what is the process to follow for curriculum change in an HEI [9] (p. 68)." Some conceptual approaches towards curricular integration of sustainability in Higher Education Institutions (HEIs) take a "matrix"-approach, looking at integration sustainability along dimensions such as disciplinarity vs. inter-(/trans)disciplinarity, or existing vs. new structures [15]. Similarly, Bellina et al. look at different areas of integrating (E)SD into HESD [16]. Their concepts are not exclusive to the curricular level, but similar to Rusinko (2009) by looking at the dimensions of disciplinarity and inter-(/trans)disciplinarity and receptive vs. participatory learning settings (ibid. p. 61ff.). Another approach differentiates different levels of curricular integration from "add on" offers to "built-in" contents (ibid. p. $47 \mathrm{ff}$.) The present study constitutes a step previous to this, by looking at the current state of curricular integration of (E)SD with regard to level (Q2) and type (Q3) of degree (discipline).

In addition to theoretical, conceptual, and application-oriented literature, the longstanding interest of researchers in the subject has produced a multitude of case studies e.g., $[15,17,18]$. Calls for meta-analysis' of single case studies on the implementation of sustainability in curricula have been there for some time $[19,20]$, recent and upcoming meta-analyses are producing promising new findings [21]. The meta-analysis by Weiss and Bath [21] provides an initial overview of the global state of research on the implementation of sustainability in the curricula of higher education institutions. An increasing number of papers have been published on this topic in a wide variety of journals. A clear focus of research is taking place in the "Western world", where findings are well linked to each other. Thus, there is a not only need for more research in "non-Western" countries. More research is needed on concrete anchoring of sustainability into curricula and how to learn from such case studies and implementation patterns. Although the present study has a case study design (the case being the entire state or the individual university, depending on the question, see Section 2. Materials and methods), it can equally be conceptualized and understood as a meta-analysis: By examining the curricula of 374 study programs (or potential cases) and putting them into a broader context, the study aims at providing an overview of the status quo of sustainability in HEI curricula throughout the state.

The present study relates to similar research projects from other countries and universities: In eight HEIs in Latin American countries, Chile, Colombia, Mexico, and Peru, the status quo of the curricular anchoring of ESD was investigated. The focus was on undergraduate programs, whose curricula were examined for sustainability references [22]. Bachelor's and Master's degree programs at Portuguese public HEIs were examined to determine whether they address the SDGs [23]. In the UK, Fiselier et al. [24] explored 16 HEIs that have made significant progress in implementing ESD into the curriculum 
to determine their distinguishing characteristics and success factors (findings that can serve as a reference for future work with results of the present study). Other studies focus on specific faculties and degree types when anchoring ESD in higher education institutions. Novo-Corti et al. [25] examine this among masters and PhD students from business faculties at universities in Romania. In the framework of the project, EDINSOST (Educación e Innovación Social para la Sostenibilidad), to train agents of change to address the challenges facing society, Spanish universities have been researching the curricular anchoring of sustainability in different disciplines. Sánchez-Carracedo et al. [26] studied ten engineering programs at different Spanish universities. Muñoz-Rodríguez et al. [27] focused on the case studies of four undergraduate programs (Early Childhood Education Teacher, Primary Education Teacher, Pedagogy, and Social Education) at the University of Salamanca. A similar study was conducted at the University of Sevilla for the Bachelor of Education (Early Childhood Education, Primary Education, and Pedagogy) [28].

The goal of the present study is to determine the status quo in terms of the anchoring of the subject of sustainability in the curricula in the study programs of the state of Brandenburg. The study pursues this goal with regard to both (1) the research interest contributing to the National Monitoring on ESD at the state level [29-31] and (2) the application-oriented interest of integrating (E)SD in Higher Education curricula throughout the state as is the goal of the current Higher Education Contracts [1]. In order to obtain a complete overview of the state of sustainability in the curricula at the state level and to provide a baseline for both a comprehensive and wide-scale monitoring at the state level, such as for the integration (E)SD into Higher Education Curricula, we studied all under- and postgraduate study programs available in the state. Using the method of quantitative content analysis, the study and examination regulations and the module descriptions of all 374 listed bachelor's and master's study programs at the eight public universities in Brandenburg were examined by searching for the term "sustainability" (in German and English). The study, therefore, ties in with the National Monitoring of Education for Sustainable Development in Germany from 2018 onwards [29-31]. This is the first time that data has been recorded in a systematic and comprehensive way on a statewide level (Brandenburg).

The study investigates six independent variables which lead us to findings on (1) the extent to which sustainability is anchored in the curricula in the study programs, (2) the level of degree awarded for the study programs, (3) the type of degree awarded for the study programs, (4) the level at which sustainability is anchored (the type of document) (5) the context of the reference to sustainability in the study and examination regulations, and (6) the context of the reference to sustainability in the module descriptions.

When we speak of a "reference" to sustainability, we mean the term/concept being mentioned in the documents analyzed (in German: "Nachhaltigkeitsbezug"). When we speak of sustainability being "anchored" or the "anchoring" of sustainability in the curricula, we mean the state/process of implementation or embedding the concept of sustainability in the curricula (in German: "Verankerung"). So if a document makes references to the term sustainability, we consider the issue of sustainability to be anchored in the curriculum (for further specification, see chapter 2, especially definition of independent variables, categories and indicators).

With this quantitative database, the results provide a starting point for considerations on the further anchoring of sustainability in the curricula in the universities of Brandenburg and thus on the implementation of goals and paths for development in sustainability policy and university policy at a federal state level [1,2].

\subsection{The Role Played by Sustainability in University Curricula in Achieving Sustainable Regional Development}

Universities have an influence on regional development in various areas. This chapter starts with a description of the different roles of universities in regional development and a clarification of the basis on which our study builds on at the Eberswalde University for Sustainable Development. The chapters' main focus is on how the state of Brandenburg takes up the role of universities in the context of regional development (Transfer Strategy, 
Sustainability Strategy, and Higher Education Contracts). We end the section by illustrating the concept of (Higher) Education for Sustainable development and its' relevance in regional sustainability development.

Reimer and Miosga highlight five areas in which universities have an influence on regional development: (1) Universities and their employees and activities represent an important economic factor and are required to (2) ensure the necessary supply of academic skilled workers, in particular for the regional market. In addition to this, the universities (3) have acquired a further area of responsibility in the past few years, namely knowledge transfer and technology transfer. New and less researched fields are the influence of universities (4) in regional development and (5) on engagement in civil society [32] (p. 130). Findler et al. [33] address the impacts of HEIs on sustainable development in a meta-analysis. There are direct effects (for example, "qualified workforce" or "GHG emissions caused by operations") and indirect effects (for example, "economic growth" or "change of societal and business practices") that can result from the activities of universities. At the same time, the meta-study reveals that there is a need for further research in order to concretize the impact of universities on sustainable development. Blume et al. [34] analyze the role of universities and sustainable regional development in their special issue. They find that universities, not as institutions but individual university members who are involved in sustainable initiatives, are the ones who mainly contribute to sustainable regional development. With regard to HESD, this means that through the transdisciplinary production of knowledge and transformative research and education, universities are now starting to become more active in their regional frameworks for action, which constitutes a significant requirement for change [32,35,36]. The Federal Government's Academic Council for Global Environmental Change (Wissenschaftlicher Beirat der Bundesregierung Globale Umweltveränderungen, WBGU) points to the necessity for active shaping of this change through research and education in their report "Welt im Wandel-Gesellschaftsvertrag für eine Große Transformation" [A changing world-social contract for a major transformation] [37] (p. 341). From the perspective of transformative academia, it is no longer only systems knowledge that is required but also knowledge of targets and transformation $[35,36]$. The transformation knowledge acquired through research formats such as living labs ultimately contributes towards the shaping of change processes $[35,36,38]$. If universities are to play an active role in the shaping of the regional transformation towards sustainability, the passing on of transformation knowledge through practice-based and competency-based university teaching, as well as through Education for Sustainable Development, must be incorporated into university teaching [35,37].

Our study builds on the goal of the University for Sustainable Development Eberswalde to anchor (E)SD in Higher Education teaching, based on its underlying understanding of sustainability and a whole institution approach. The goal of the universities' Transfer Strategy and its resulting Sustainability Transfer is to develop practice- and competence-oriented university teaching through collaborations between university and practice [39-41]. In this context, the present study in Brandenburg can help to provide an overview of the anchoring of (E)SD in university teaching, taking all universities in Brandenburg into account and showing references to sustainable development in the region.

The study can draw on political goals at the state level which have been formulated such as the Transfer Strategy Brandenburg [42] as well as the state's Sustainability Strategy [43]. The Transfer Strategy defines (inter alia) the role of universities in regional development. In the Sustainability Strategy, the focus regarding the universities is placed on the promotion of important competencies that will ensure that both the graduates themselves and the universities as key players are able to contribute to regional development in the drive towards sustainability. The anchoring of sustainability in teaching, research, university governance, and transfer in the Brandenburg Higher Education Contracts represents an important step by the federal state authorities in terms of implementation [1].

With their Brandenburg Transfer Strategy, the state government underlines the great importance of the academic institutions in successful regional development and reinforces 
the transfer activities of the academic institutions [42]. The active role played by the universities in regional development is reflected in the local offices of the universities, which provide a presence in the regional centers of growth across the federal state [42]. In Schwedt in the Uckermark region, for example, the local office of the University for Sustainable Development is endeavoring to promote sustainable transfer, forming a connecting link between academia, the business sector, and civil society [44]. The Brandenburg University of Technology (BTU) Cottbus-Senftenberg plays an active role in the process of structural transformation in Lusatia through innovation labs, training courses, and start-up centers [45]. Nölting et al. [40] also highlight ways in which transfer activities in the region can be incorporated into university teaching via Education for Sustainable Development, making it possible for universities to take on a more active role in the regional transformation towards sustainability. In the master's program "Regional Development and the Protection of Nature", for example, students spend a whole semester addressing issues related to sustainable regional development in practice-based projects in which they collaborate with key players from the administrative authorities and businesses and civil society organizations [40]. The Leuphana University of Lüneburg and the Hanseatic city of Lüneburg worked together on a project called "Future City 2030+" and actively involved students in giving support to the city authorities on their path to sustainable development [46] (p. 150).

In the Brandenburg Sustainability Strategy, universities are described as "society's engines for innovation" [43] (p. 70). They are integrated into a "sustainable education landscape" [43] (p. 69) and are an important component for the development of possible solutions to deal with major challenges, for example, the consequences of the climate crisis [43]. In the updated Brandenburg Sustainability Strategy, the role of the university regarding the provision of skilled workers for the region is put into more concrete terms [2]. Here, reference is made to the 17 Sustainable Development Goals [5] and to the National Action Plan for Education for Sustainable Development [6] in which this goal has already been formulated. Goal 4.1 is to "encourage and support students and graduates as key shapers of sustainable development and to allow them to participate in a serious way" [2] (p. 3).

In accordance with this, the federal state authorities and their public universities have agreed in the Higher Education Contracts (2019-2023) for the state of Brandenburg on the integration of sustainability into the university system. The anchoring of "Education for Sustainable Development in the consciousness of all members of the university" [1] (p. 8) is to be brought about through the development of university-specific ways of accessing ESD, work on mission statements, and capacity-building for teaching staff, as well as through the anchoring of ESD and sustainability in the curricula [1]. Representatives of the eight public universities in the federal state are currently working on this plan as members of the working group for the anchoring of "Sustainability at Brandenburg Universities" [47]. The fact that the current Higher Education Contracts in Brandenburg include ESD, reflects the national "strong trend towards anchoring ESD within the target agreements between the federal states and the higher education institutions [ ... ]" [31] (p. 13). The progress report of the National Monitoring on ESD [30,31] concludes: "impulses have mainly come from state initiatives rather than from the institutions [or self-governing bodies] themselves, pointing to the need for further strategies to strengthen sustainability/sustainable development within the higher education institutions" ibid, see also [48]. The present study wants to contribute to the development of these strategies by providing a sound foundation for future curricular reform towards the integration of ESD.

The goal of Education for Sustainable Development is to foster the development of competencies needed to shape the future in a more sustainable way $[6,16,49-53]$. In the international discussion on "competencies" or "skills" relevant to sustainable development, different terms are being used. "Shaping competency" (in German "Gestaltungskompetenz") is widely used in the German discourse, while "key" or "core" competencies are more common in international discourses. Prominent examples for key competency models are UNESCO 2017 [51] and specifically for the higher education sector Wiek et al. 2011, fur- 
ther developed by Brundiers et al. [49,53]. Brundiers et al. describe these competencies as systems-thinking competency, future-thinking competency, strategic-thinking competency, values-thinking competency, and implementation competency in combination with intraand interpersonal competency such as integrated problem-solving competency [49].

These competencies are developed through specific didactic principles (e.g., participation) in transformational learning settings, working on matters of concern to sustainability (topics such as mobility, nutrition, consumption, etc.), and by encouraging students to reflect on their own values in relation to their own understanding of sustainability and the way they act $[10,54]$. A practice-oriented learning setting is particularly well-suited for the development of these competencies; learning settings in which students, teaching staff, and players from the actual practice work together as equals to address sustainability problems and develop strategies to solve them [40,54-57]. This is particularly the case in the context of universities acting as a key player in the regional transformation towards sustainability [32,58]. Didactical learning settings like this can be seen, for example, in project workshops [18] and in Service Learning [59-61] as well as in many other examples, such as the CREAPOLIS Makerspace at the Coburg University of Applied Sciences [62] (p. 80) or the Local Mobility Teaching Module at the Technical University (TU) of Berlin [63] (p. 68). The settings and formats for learning have a proven impact on both the further development of sustainability-related thinking and acting and on the regional environment and its key players $[10,64,65]$.

With this in mind, Education for Sustainable Development in university teaching is of great relevance for regional development processes with its competency-based and practice-oriented approach to teaching. Once the educational concept has been established in the curricula [1] - which are composed of module descriptions, study and examination regulations- the state's universities can position themselves as active drivers of sustainable development. The universities of the state of Brandenburg vary in size and profile as shown in Table 1. This needs to be taken into consideration for the university-specific interpretation of the results and development of further recommendations (see Chapter 2, study design and quantitative design, and Chapter 4, discussion of results, especially results of Q2 and Q3) (For the purpose of our study, we chose to anonymize the university-specific result, portraying quantitative data in relative numerical values. In the context of this study, we are focusing on Higher Education at the state level as a whole with regard to its potential for future sustainable regional development. The individual universities, however, were provided with their specific results.).

Table 1. Overview of the universities of Brandenburg and the number of members of each university.

\begin{tabular}{cccc}
\hline Brandenburg Universities & $\begin{array}{c}\text { Number of } \\
\text { Students [66] }\end{array}$ & University Staff [67] & $\begin{array}{c}\text { All Members of the } \\
\text { University }\end{array}$ \\
\hline KONRAD WOLF Film University of Babelsberg & 817 & 359 & 1176 \\
Viadrina European University, Frankfurt (Oder) & 1001 & 705 & 7438 \\
Eberswalde University for Sustainable & 2110 & 576 & 2686 \\
Development & & & \\
Brandenburg University of Technology, & 2594 & 1855 & 3870 \\
Cottbus-Senftenberg & 2649 & 456 & 3105 \\
Brandenburg University of Applied Sciences & 3443 & 710 & 4153 \\
Potsdam University of Applied Sciences & 3646 & 748 & 4394 \\
Technical University of Applied Sciences, Wildau & 20,881 & 4765 & 25,646 \\
University of Potsdam & 47,259 & 11,209 & 58,468 \\
Total number in the project & & \\
\hline
\end{tabular}

In addition to anchoring ESD in the curricula of the study programs, a further factor that is therefore of particular importance is the extent to which sustainability has been anchored in the curricula, both in the bachelor's and master's study programs and in the various different disciplines. It will therefore become clear, on the one hand, whether possession of the required competencies is to be expected of the graduates of a bachelor's or 
master's study program. On the other hand, taking a look at the various different types of degree can give an indication as to the disciplines where students and graduates are likely to have the knowledge and competencies related to sustainability that will allow them to make a positive contribution in the regional transformation towards sustainability-a task that is facing the whole of society.

\subsection{Current State of Sustainability in the German Higher Education System}

This chapter introduces the method and findings of the National Monitoring on (Higher) Education for sustainable development. Focusing on the document analysis of Higher Education curricula, both the research interest and research question of our study are being developed.

The National Monitoring on Education for Sustainable Development examines the status of implementation of ESD in early childhood education, school education, higher education, and vocational education and training. The first document analyses of 2795 documents utilized an indicator-based lexical content analysis $[29,31,68]$. The indicators were developed from literature and international indicators on education monitoring in general and on the progress of ESD implementation [69-74] and adapted to the national context. For the area of higher education, the Higher Education Acts are examined to determine the extent to which ESD is anchored in national and federal legislation. The anchoring of ESD in the framework documents relevant to policymaking (education and sustainability strategies) is determined by looking at the National Education Report/Higher Education, the (state-level) University Development Plans, the Target agreements (or Higher Education Contracts) between states and institutions of higher education and the resolutions of the German Rectors' Conference (HRK) and the State Rectors' Conference (LRK). For the monitoring of networking activities and whole-institution approaches, award-winning and other university networks for ESD are investigated, as well as award-winning (ESD) universities.

Of particular relevance to the context of the present study is the section of the National Monitoring that examines ESD in the curricula [38]. The document analysis examined the anchoring of ESD in selected study programs (Biology, Business Administration, and Mechanical Engineering and related concepts) by looking at instances where sustainability was mentioned in different document types which compose the curricula: study and examination regulations, module handbooks, and study program flyers. The following search terms were used as the basis for the analysis: Education for Sustainable Development, sustainability, sustainable, sustainable development, sustain, shaping competency (in German "Gestaltungskompetenz", refers to the skills needed to shape the future in a more sustainable way), intercultural education and environmental education (ibid.). (The progress report of the National Monitoring on ESD added the search terms "Transformative learning/Education" and "Climate education" [30,31].) As module descriptions, for example, tend to describe the content and specific educational goals, the search terms that could be found most frequently in the selected study programs were "sustainable" (47.4\%), "sustain" (23.3\%), and "sustainability" (22.6\%). Terms referring to educational concepts were found less frequently; for environmental education in just $1.9 \%$ of cases, ESD and "Gestaltungskompetenz" (shaping competency) in only $0.4 \%$ of cases, and intercultural education in $0 \%$ of cases (ibid.) With these results in mind, the terms used for this current study were solely "sustainable" and "sustain", as it was assumed that this would be the best way to arrive at the relevant results (see below: Q1).

The National Monitoring placed the focus on selected bachelor's study programs (Biology, Business Administration and Mechanical Engineering and related concepts) at selected universities (a total of 15 across the whole of Germany). These universities and universities of applied sciences were selected according to their strength in terms of research and the size of the universities. Universities providing teacher training were selected based on the highest numbers of graduates in the winter semester 2013/14, the largest universities, universities of applied science, in terms of the number of graduates in the winter semester 2015/16. A further prerequisite for selection was that the universities 
or universities of applied sciences had to offer two of the three selected bachelor's study programs. In addition to this, three lighthouse universities were included in the study whose focus is on the field of sustainable development (Leuphana University of Lüneburg, Eberswalde University for Sustainable Development, University of Tübingen). From the findings, the assertion was made that eight out of these 15 universities had succeeded in anchoring (E)SD into their structure, as they all had several modules that made reference to sustainability (these were the three lighthouse universities, as well as the University of Cologne, the RWTH Aachen University, the Dresden University of Technology, the University of Stuttgart, and the Munich University of Applied Sciences). However, the assertion can only be considered to apply to undergraduate study programs, as only bachelor's study programs were included in the study. For our present study, however, a complete survey was conducted in order to be able to make assertions on all the universities in Brandenburg and all the study programs being offered (see below: Q3). Therefore, not only bachelor's but also master's study programs were included in order to investigate how sustainability is anchored in post-graduate study programs (see below: Q2). "To sum up, it can be concluded that there is in-depth anchoring of (E)SD where (1) a high level of commitment to sustainability is shown in the modules of the relevant study and examination regulations or in the module description and (2) there is a comprehensive offer of modules in the study programs [29] (p. 219, authors' translation)." Following this approach, we here examined the study and examination regulations and the module descriptions using search terms related to sustainability (see below: Q4-Q6) in order to be able to make assertions on the extent of the anchoring of (E)SD and the level of commitment shown in this regard.

The research question of our study and its six sub-questions were developed out of the National Monitoring on ESD $[29,31]$. This development was led by guiding questions on the current status of (E)SD in Higher Education Curricula in the state of Brandenburg. Answers might provide a basis for recommendations on how to anchor (E)SD in Higher Education Curricula at the state level [1,2] (as described in Chapter 2). The research question for the study is as follows: How and with what frequency is sustainability anchored in the curricula of study programs in Brandenburg? What quantitative statements can be made on the anchoring of sustainability in study programs in Brandenburg as regards the level of degree awarded, the type of degree, and the level and context of the anchoring? From the above, six sub-questions were derived:

- Q1: What percentage of the study programs show evidence of reference being made to sustainability?

- Q2: What role is played here by the level of degree awarded, i.e., bachelors or masters? Is there more evidence of a reference to sustainability in bachelor's study programs or in master's study programs?

- Q3: In terms of the type of degree awarded (Sc., Arts, etc.), which study programs show more evidence of a reference to sustainability?

- Q4: Is sustainability anchored at the level of study and examination regulations and/or module descriptions (types of documents)?

- Q5: In what context do study and examination regulations show evidence of reference being made to sustainability?

- Q6: In what context do module descriptions show evidence of a reference to sustainability?

This study pursues two areas of interest for research. Using the research desideratum of the National Monitoring on the anchoring of ESD in higher education [29] as a starting point, the results from the present study, which focuses on one federal state only, can contribute to a comprehensive, systematic, and more wide-scale monitoring on a national level. As well as an academic interest, an application-focused interest is being pursued: as a coordinating body for the anchoring of sustainability in Brandenburg universities, we would like to offer support to the universities with this review of the current situation. The results, which highlight those study programs in which sustainability is anchored (and the extent to which this is the case) can provide an indication of the status quo of the anchoring 
of sustainability in the curricula. They can also form a starting point for the strategic development of the universities in terms of anchoring sustainability in their curricula.

\section{Materials and Methods}

The following is a presentation of the study design and the development of research questions, variables, and indicators. Details are then presented of the practical approach taken to carrying out the research as well as the quantitative design, the cross-university, and university-specific evaluation in the context of the document analysis.

Study design: The object of the investigation is the anchoring of sustainability in the curricula of Brandenburg study programs. The study involved the conducting of case studies. In the cross-university evaluation, one case is examined; the distinguishing criterion here is the federal state (results to Q1-6). In the university-specific evaluation, eight cases are examined; here the distinguishing criterion is the (public) university (in this paper results on Q1-2, whereas the university-specific results on Q3-6 were provided individually to the university in question). As in the National Monitoring on (H)ESD [29-31], this study used an indicator-based lexical content analysis [68]. The collection of data [75-82] and evaluation of data were done by means of a document analysis [83]. The evaluation of the 748 curricular documents (study and examination regulations and module descriptions) was done according to quantitative criteria. The structure of the research design was supported by the work of Gläser and Laudel [84], which the authors find very helpful for conceptualizing content analyses.

The curriculum of a study program was defined as the dependent variable. The selection criterion was the level of degree at bachelor's or master's level (This also includes some exceptions, such as the first state examinations in Law, in this case assigned to the level of a Bachelor, whilst doctoral study programs were not included.) Study programs that were being discontinued were not taken into consideration, provided this had been made clear, for example, by means of a note on the website of the university in question. In contrast to the National Monitoring [29], the study was not restricted to certain disciplines. The goal of this study was to carry out a statewide, comprehensive investigation of all study programs and disciplines. In accordance with this, we were interested in the total amount of empirical units for our investigation (population) and data was collected from 374 study programs at public universities across Brandenburg.

Development of research questions, variables, and indicators: The research question was divided into six sub-questions (Q1-Q6). These sub-questions were developed from the desideratum of the National Monitoring on ESD [29,31], (see Chapter 1.2) and from guiding questions of this study on how to provide recommendations for the anchoring (E)SD in Higher Education Curricula at the state level [1,2]. The relevant independent variables were derived from these (V1-V6). The independent variables V1-3 were drawn from the National Monitoring on ESD and further developed for the purpose of our study since we wanted to investigate all study programs offered throughout the state. V1 includes all study programs instead of a sample, V2 includes both undergraduate (Bachelor) and post-graduate (Masters) level of degrees, and V3 includes all types of degrees available in the state instead of a sample. V4-6 were developed as a tool for this study by relating the two document types to each other (V4). Similarly, V5-6 were developed out of the structure of the document types themselves. In order to be able to detect "quantitative tendencies", we assigned category values for V4-6 (see Table 2). Waltner et al. proceeded in a similar way in the development of an ESD indicator for teacher training. When analyzing the relevance of ESD in teacher training courses they differentiated ESD-relevant content and targets (goals) of the courses and assigned category values. Courses were classified as highly ESD relevant if they contained both categories [85]. 
Table 2. Independent variables, categories of variables, and indicators.

\begin{tabular}{|c|c|c|}
\hline Independent Variable & Category & Indicator \\
\hline $\begin{array}{l}\text { V1 Study program/ } \\
\text { anchoring of sustainability in the } \\
\text { curriculum }\end{array}$ & $\begin{array}{ll}- & \text { with reference to sustainability } \\
\text { - } & \text { without reference to sustainability }\end{array}$ & $\begin{array}{l}\text { Mention of nachhaltig*/sustain }{ }^{*} \text { in the study } \\
\text { and examination regulationsand/or module } \\
\text { descriptions }\end{array}$ \\
\hline V2 Level of degree & $\begin{array}{l}\text { - } \quad \text { Bachelor's } \\
-\quad \text { Master's } \\
\text { with/without reference to sustainability }\end{array}$ & $\begin{array}{l}\text { Mention of nachhaltig*/sustain }{ }^{*} \text { in study } \\
\text { programs with the degree (level): } \\
\text { - } \quad \text { Bachelor's or } \\
\text { - } \quad \text { Master's }\end{array}$ \\
\hline V3 Type of degree & $\begin{array}{ll}- & \text { Bachelor/Master of Arts } \\
- & \text { Bachelor/Master of Education } \\
- & \text { Bachelor/Master of Engineering } \\
- & \text { Bachelor/Master of Fine Arts } \\
- & \text { Bachelor/Master of Laws } \\
- & \text { Bachelor/Master of Science } \\
- & \text { Further master's degrees } \\
\text { with/without reference to sustainability }\end{array}$ & $\begin{array}{l}\text { Mention of nachhaltig*/sustain* in study } \\
\text { programs with the following types of degree: } \\
\text { Bachelor/Master of Arts, of Education, of } \\
\text { Engineering, of Fine Arts, of Laws, of Science } \\
\text { and further types of master's degree }\end{array}$ \\
\hline $\begin{array}{l}\text { V4 Type of document/level } \\
\text { of anchoring }\end{array}$ & 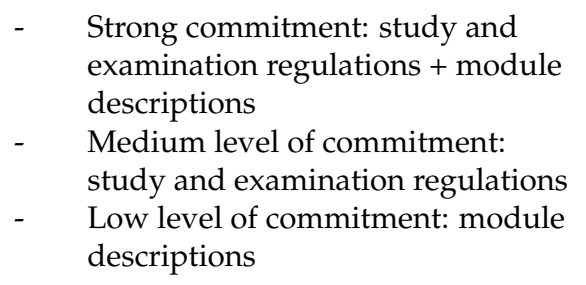 & $\begin{array}{l}\text { Mention of nachhaltig*/sustain* in the } \\
\text { following types of document: } \\
\text { - } \quad \text { Study and examination regulations + } \\
\text { module descriptions or } \\
\text { - } \quad \text { Study and examination regulations or } \\
\text { - } \quad \text { Module descriptions }\end{array}$ \\
\hline $\begin{array}{l}\text { V5 Context in study and } \\
\text { examination regulations }\end{array}$ & $\begin{array}{l}\text { - } \quad \text { Strong anchoring: main document } \\
\text { and attachment } \\
\text { - } \quad \text { Medium level of anchoring: main } \\
\text { document } \\
\text { - } \quad \text { Low level of anchoring: attachment }\end{array}$ & $\begin{array}{l}\text { Mention of nachhaltig*/sustain* in the } \\
\text { - } \quad \text { Main document and attachment or } \\
\text { - } \quad \text { Main document or attachment }\end{array}$ \\
\hline V6 Context in the module description & $\begin{array}{l}\text { - } \quad \text { Strong anchoring: three indicator } \\
\text { categories } \\
\text { - } \quad \text { Medium level of anchoring: two } \\
\text { indicator categories } \\
\text { - } \quad \text { Low level of anchoring: one } \\
\text { indicator category } \\
\text { - No indicator categories }\end{array}$ & $\begin{array}{l}\text { Mention of nachhaltig*/sustain }{ }^{*} \text { in the } \\
\text { following categories: } \\
\text { - } \quad \text { Title of the modules and/or } \\
\text { - } \quad \text { Goals of the modules and/or } \\
\text { - } \quad \text { Content of the modules }\end{array}$ \\
\hline
\end{tabular}

The following is a presentation of the sub-questions of the research question (Q1-Q6), the corresponding independent variables (V1-V6), and the guiding questions of the study in order to show the reasoning behind both sub-questions and independent variables. The different categories of variables and the indicators in each case are presented to follow in Table 2.

- Q1: What percentage of the study programs show evidence of reference being made to sustainability? V1: Anchoring of sustainability in the curriculum We started with the question: Is there evidence of reference being made to sustainability in the study programs? If the answer is yes, then in how many of the study programs and in which study programs? In accordance with this, we first established if the term "sustainability" came up in any of the documents forming part of the curriculum for the program.

- Q2: What role does the level of degree awarded play, i.e., bachelor's or master's degree? Is there more evidence of a reference to sustainability in bachelor's study 
programs or in master's study programs? V2: Level of degree awarded for the study program We were also interested to find out whether the subject of sustainability tended to be addressed to a greater extent in undergraduate or in post-graduate studies. The fact that the subject of sustainable development is of such far-reaching significance for society means that it is essential that the concept is dealt with in undergraduate study programs. Yet, at the same time, it is a complex concept and, bearing in mind the specialization that takes place during a master's degree, it may in fact be better suited to being dealt with in a master's study program.

- Q3: In terms of the type of degree awarded (Sc., Arts, etc.), which study programs show more evidence of a reference to sustainability? V3: Type of degree awarded for the study program Here we asked whether there was evidence that sustainability was being dealt with to a greater extent by certain disciplines and less so in others? The grouping of study programs according to discipline could have been done using various different types of systemization (see Chapter 4). Clear categorization of the study programs made it possible to have a criterion "Type of degree" for which sustainability was mentioned in study programs, with the following degree types: Bachelor or Master (grouped) of Arts, of Education, of Engineering, of Fine Arts, of Laws, of Science and other types of master's degree.

- Q4: Is sustainability anchored at the level of study and examination regulations and/or module descriptions (types of documents)? V4: Level at which sustainability is anchored (types of documents) With a view to the function of the types of documents examined, we asked the question as to which types of documents contained a reference to sustainability. There are two suppositions behind this: (1) The subject of sustainability is considered to be more "strongly anchored" in a study program when the subject is mentioned in both the study and examination regulations and also in the module descriptions. (2) A higher level of commitment to the subject of sustainability is demonstrated if it is mentioned in the study and examination regulations than is the case if it is mentioned in the module descriptions.

- Q5: In what context do study and examination regulations show evidence of reference being made to sustainability? V5: Context of the reference to sustainability in study and examination regulations With a view to the question as to how "strongly" sustainability is anchored in the study and examination regulations, we differentiated in terms of the context in which the reference to sustainability was found. This was based on the assumption that the subject of sustainability can be considered to be "more strongly anchored" if it is mentioned in both the main document and in the attachment of a set of study and examination regulations.

- Q6: In what context do module descriptions show evidence of a reference to sustainability? V6: Context of the reference to sustainability in the module descriptions The same applies with regard to the question as to how "strongly" sustainability is anchored in the module descriptions. This was based on the assumption that the subject of sustainability can be considered to be "more strongly anchored" if it is mentioned in the titles, goals, and content of the module descriptions.

The indicator for a reference to sustainability for all six independent variables and for their various categories was in each case the mention or non-mention of the term "sustainability". Following the example of the National Monitoring, the search terms used were nachhaltig*/sustain* (German, English), from which we also derived the terms sustainability and (Education for) Sustainable Development (in all noun, adjective, and separable forms in German (Nachhaltigkeit, nachhaltige, nach-haltig, etc.) and English (sustainability, sustainable, sus-tainable, etc.)). In the following, the various terms will be reduced to simply "sustainability", by which we mean all the terms listed above. We did not include occurrences where the term "sustainable" was used in the sense of "long-term" and not in the context of "sustainable development", in line with the established understanding - since the publication of the Brundtland Report—of an (at least) environmentally friendly, economic and socially sustainable form of development that 
aims at intergenerational and intragenerational justice [86]. In contrast to the approach taken by the National Monitoring [29], we refrained from including the terms "shaping competency", "intercultural education" or "environmental education" in our search. (On the one hand, the search had already been less fruitful in these cases, presumably because the terms deal with educational concepts and therefore with a meta-level that is usually only addressed this explicitly in documents reflecting the perspective of education theory. On the other hand, the search could have been expanded to include a multitude of further terms, e.g., subjects related to sustainable development, such as health, gender equality, and climate protection, such as those named in the SDGs and which are dealt with in Education for Sustainable Development $[18,87]$ or at the meta-level, educational concepts such as "global learning". An appropriate limitation of the themes whilst ensuring that students do address the concept of sustainability in the respective study program without the term "sustainability" being mentioned would have made it necessary to set up a separate research project.) The decision to focus on the term "sustainable" /"sustain" therefore resulted in a very narrow but well-demarcated search criterion.

The design of the present study focuses on sustainability contents at the curricular level and does not explicitly include the examination of sustainability competencies and suitable methods/didactical approaches for fostering these competencies. However, the acquisition of knowledge on sustainability can be assumed with students and future professionals that have graduated from study programs with sustainability contents; they, therefore, (ideally) have developed competencies for shaping sustainable (regional) development.

A practical approach to the research: For the collection of data, we first selected the types of documents, collected all the documents, and narrowed down the documents used. The selection criteria for the types of documents were based on the approach taken by the National Monitoring [29]. For the investigation of the reference made to sustainability in the curricula of all 374 study programs in Brandenburg, we collected all study and examinations regulations and a module description, i.e., two documents per study program [75-82] (In the National Monitoring, a further type of document was considered: "study program description/flyer" [29]. However, the examination of this type of document was not considered necessary within the scope of this study as it only arose in exceptional cases and, even then, did not have any influence on the quantitative results.). These documents are, as a rule, available on the universities' websites; where this was not the case, we requested the documents from the universities, and they were made available to us. In cases where we found new or additional documents in the course of our follow-up research, or where such documents were sent to us by the universities, they were only taken into consideration if they were of validity for the course of study in the period during which our research was carried out.

The research period was November 2019 to February 2020. The greater part of the evaluation work was done in March 2020. The results were then made available to the Brandenburg universities in the form of a summary of results and a data table. During the period of five months, from April to October 2020, the results were examined by these universities and discussed in various academic and application-oriented contexts (especially regarding findings and limitations) Following the evaluation, the results were made available to the eight universities. Here, the specific results for the university in question were in all cases presented in comparison to the overall results for all the universities considered together. The universities were invited to double-check the data and results. Most of the universities followed up on this invitation, although there were differences in the way the results were then put to use internally at the various universities: some universities passed on the results to others within the institution, some carried out a central review of the data and, in some cases, the results could only be acknowledged due to limited resources. The quantitative results of the survey remained unchanged after the review. In addition to this, the cross-university results were discussed in various application-oriented and academic contexts: at the State Rectors' Conference with the eight presidents of the Brandenburg universities (April 2020), with the working group for the anchoring of sustainability in 
Brandenburg universities (with an average of 2-3 delegates per university, May 2020) and at an international specialist conference on Education for Sustainable Development in higher education (October 2020). The results of these discussions were incorporated into the discussion on methods and results.

Two documents were examined and evaluated for each of the 374 study programs (a set of study and examinations regulations and a module description, making a total of 748 curricular documents). The unit of analysis was established according to the question being asked in each case: For sub-questions Q1-Q4, the unit of analysis was always the relevant section of text (with a reference to sustainability) in one and/or both types of document. For Q5, the unit of analysis was the section of text in the main document and/or attachment of the study and examination regulations, and for Q6, the section of text in the title/goal and/or content of the module. Differences in the presentation in terms of content or in formal terms were taken into account, in particular with regard to the module descriptions. The documents examined differ in their form, length, and design, depending on the university in question; this was particularly the case for the module descriptions. In the case of a university, for example, a summary of goals and content is always included. As the study had no separation criterion in this regard, relevant occurrences in the evaluation were always assigned to both categories. The analysis was conducted using the original documents, whilst the results were recorded in table form in an Excel spreadsheet, and where positive search results were achieved, a record was kept of the relevant section of the text.

Quantitative design, cross-university, and university-specific evaluation: The quantitative evaluation was carried out according to the questions posed. The sample size varied depending on the question; in Q1-4 all study programs throughout the state were analyzed $(n=374)$, in Q5 those study and examination regulations that make reference to sustainability were analyzed $(n=46)$, and in Q6 those module descriptions that make reference to sustainability $(n=112)$. Later, the results of Q5 and Q6 were again asked in relation to the total number of study programs $(n=374)$.

Quantification was undertaken on the level of the units of analysis. Single frequencies were determined for positive search results throughout all questions on the level of the unit of analysis. If, for example, Q1 asked if a study program makes reference to sustainability in a section of text within its curricular documents (unit of analysis), it was only relevant that it was mentioned at least once, not how often. If with Q5 the question was being addressed as to whether, at the level of the study and examination regulations, sustainability was mentioned in the main document (unit of analysis), only the fact that it was mentioned was considered to be of significance. Whether it was mentioned just once or several times within the unit of analysis was considered irrelevant for the evaluation.

The results were evaluated both across all universities (one case: federal state) and for each university individually (eight cases: public universities). The reasoning behind the quantitative design regarding this cross-university and university-specific evaluation (and the communication of those results to the universities) lies first and foremost in the application-oriented interest of the study: The universities themselves can make use of the results in order to get an overview of the situation within their own institution regarding the extent to which sustainability is anchored in certain study programs. Using this as a starting point, strategic considerations can then be made on how things are to go forward in terms of the anchoring of sustainability in the curricula, the identification of key players, etc. Furthermore, the universities can in this process find their place in a statewide context and position their university accordingly. Should comparable studies be carried out in other federal states, the results could also be used for a cross-state comparison. In this study, first, the results were analyzed at the state level across all universities. In a second step, the specific results of each university were analyzed. (In this paper, only the university-specific results of Q1 and Q2 are being described; for the remaining questions, the universityspecific results were provided to the universities in question.) Most quantitative results were depicted in relative terms. As the universities vary in terms of size and number of 
study programs they offer, this approach allows us to present the results in a manner that is to a large extent anonymized.

\section{Results}

To follow, we would like to present the results of our study on the anchoring of sustainability in the curricula of the Brandenburg universities. Quantitative statements have been made on the percentage of study programs that make reference to sustainability in their curricula (Section 3.1), at the level of degree awarded (Section 3.2) and the type of degree (Section 3.3), on the level of anchoring (types of document, Section 3.4), and in the context of the reference to sustainability, both in the study and examination regulations (Section 3.5) and in the module descriptions (Section 3.6). Finally, the research question will be answered (Section 3.7).

\subsection{Anchoring of Sustainability in the Curriculum}

On average, $30 \%$ of the overall number of 374 study programs at Brandenburg universities showed evidence of some reference to sustainability in their curricula (see Figure 1a). To arrive at this figure, we drew up a summary of the instances when the search term was mentioned in the study and examination regulations and/or the module descriptions (for a differentiated picture, according to whether the term was mentioned in one or both types of document, see Section 3.4).

In order to view the results in the wider context, i.e., to make a systematic comparison with other federal states, it would be necessary to carry out the relevant studies. Within the federal state itself, the findings initially appear to be positive: with a view to the further structural anchoring of sustainability in Brandenburg study programs, it would seem that there is already a good foundation that can be built upon.

Differences become clear in the comparison of the university-specific results. If we exclude "the extremes" (two universities with evidence of reference to sustainability in either $100 \%$ or $0 \%$ of the curricula), the picture appears to be differentiated: whilst three universities achieved results that were at or near the average level for the federal state, and two further universities were a little below this level, one university was significantly above the state average, with $63 \%$ of their study programs showing evidence of a reference to sustainability (see Figure 1b).

\subsection{Level of Degrees Awarded for the Study Programs}

There is approximately the same number of bachelor's study programs in Brandenburg as there are master's study programs. Both show evidence of a reference to sustainability in their curricula to an approximately equal extent (see Table 3).

On average, $29 \%$ of all master's study programs and 31\% of all bachelor's study programs show evidence of a reference to sustainability (see Figure 2a). In accordance with this, sustainability is addressed to an equal extent in undergraduate studies and post-graduate studies, thus leading to the development of both basic level knowledge and specialist knowledge in the field. 


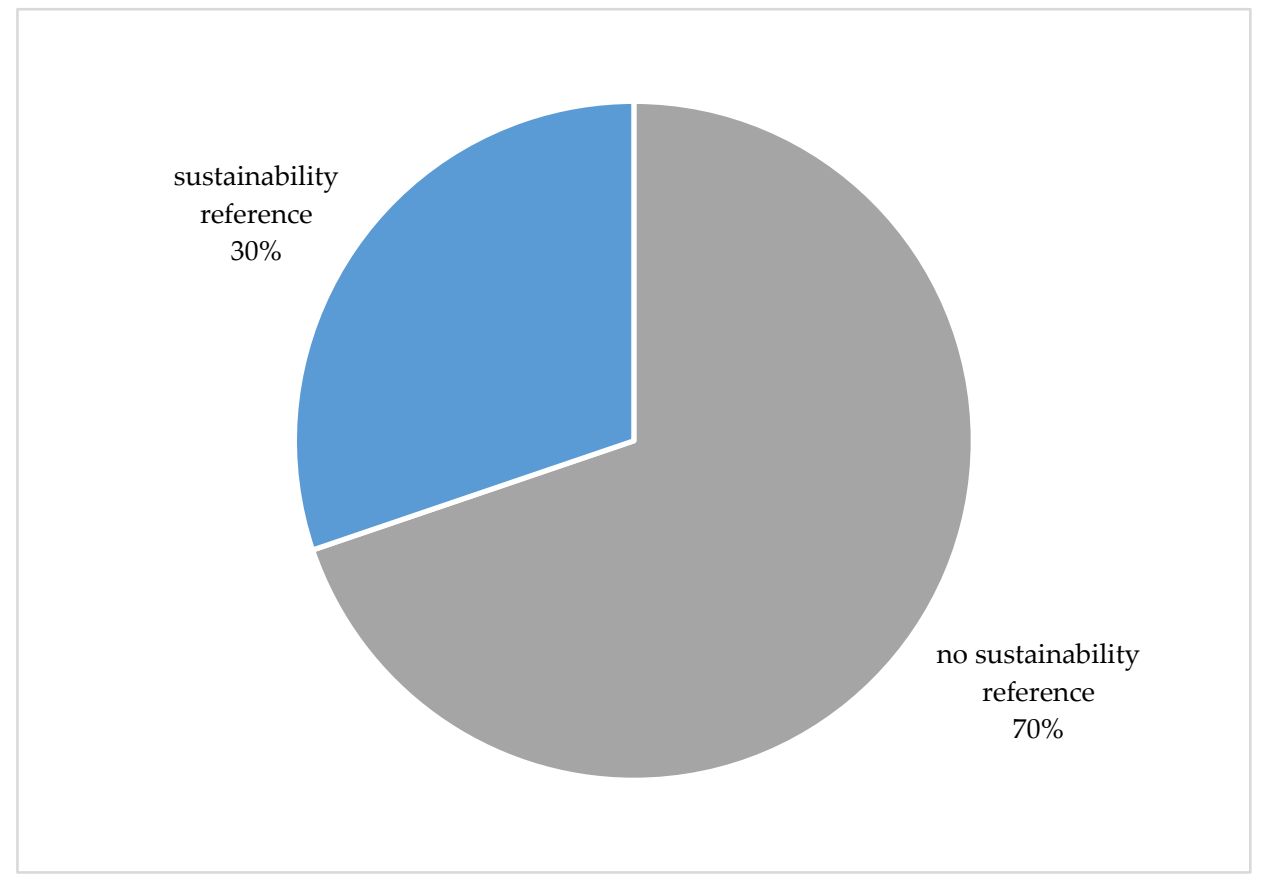

(a)

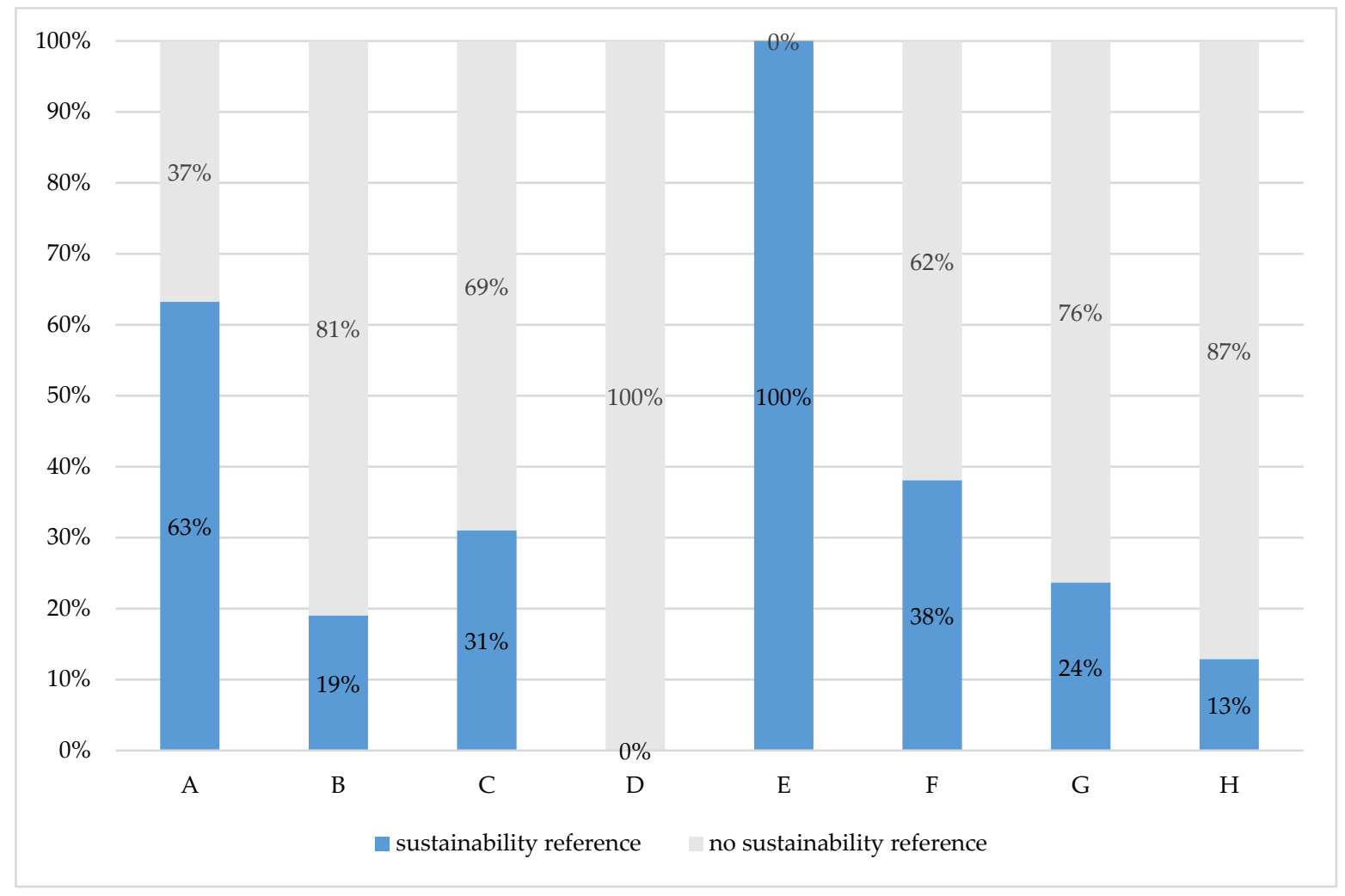

(b)

Figure 1. (a). Brandenburg study programs with and without a reference to sustainability in their curricula $(n=374)$; in percent. (b). Brandenburg study programs with and without a reference to sustainability $(n=374)$ according to university, from $\mathrm{A}$ to $\mathrm{H}$; in percent. 
Table 3. Brandenburg study programs with and without a reference to sustainability according to the level of degree awarded $(n=374)$; absolute values.

\begin{tabular}{cccc}
\hline Level of Degree & $\begin{array}{c}\text { Number of Study Programs with a } \\
\text { Reference to Sustainability }\end{array}$ & $\begin{array}{c}\text { Number of Study Programs without } \\
\text { a Reference to Sustainability }\end{array}$ & $\begin{array}{c}\text { Total } \\
\text { Bachelor's }\end{array}$ \\
Master's & 57 & 126 & 183 \\
Total & 113 & 261 & 191 \\
\hline
\end{tabular}

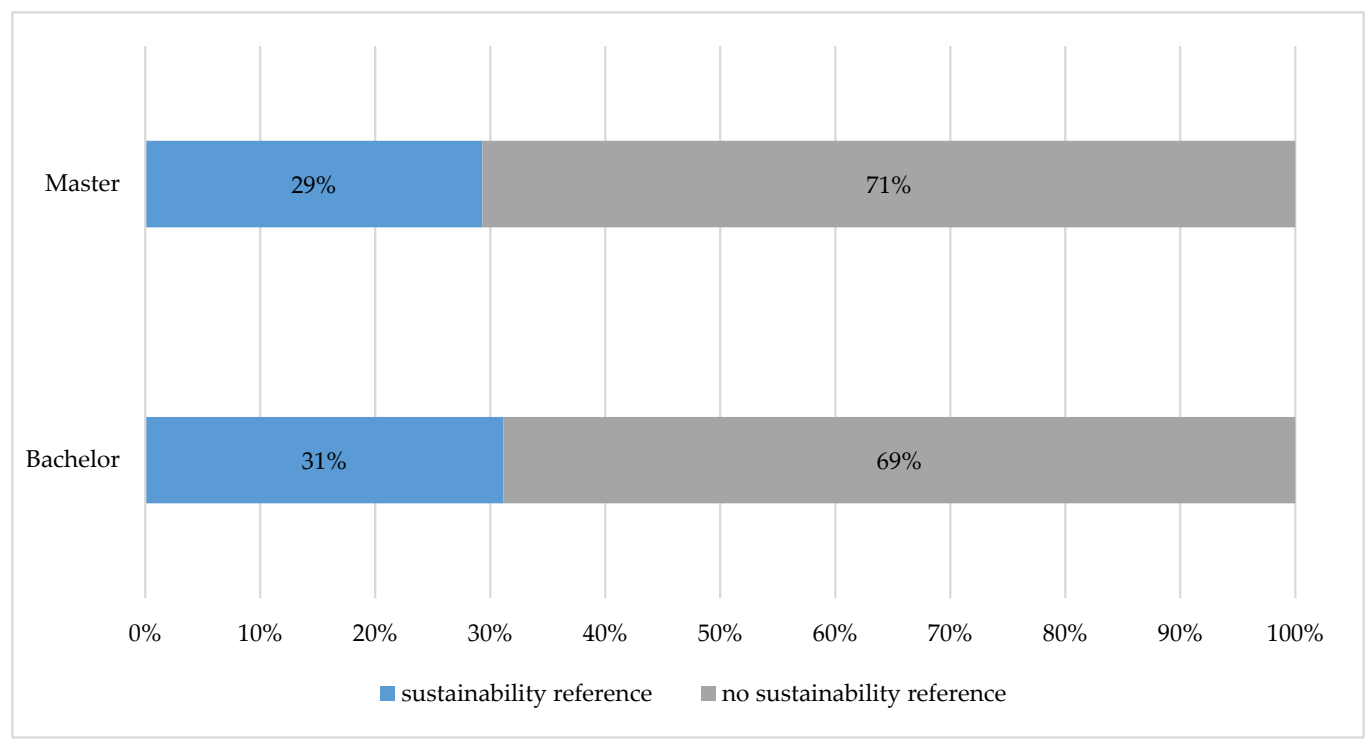

(a)

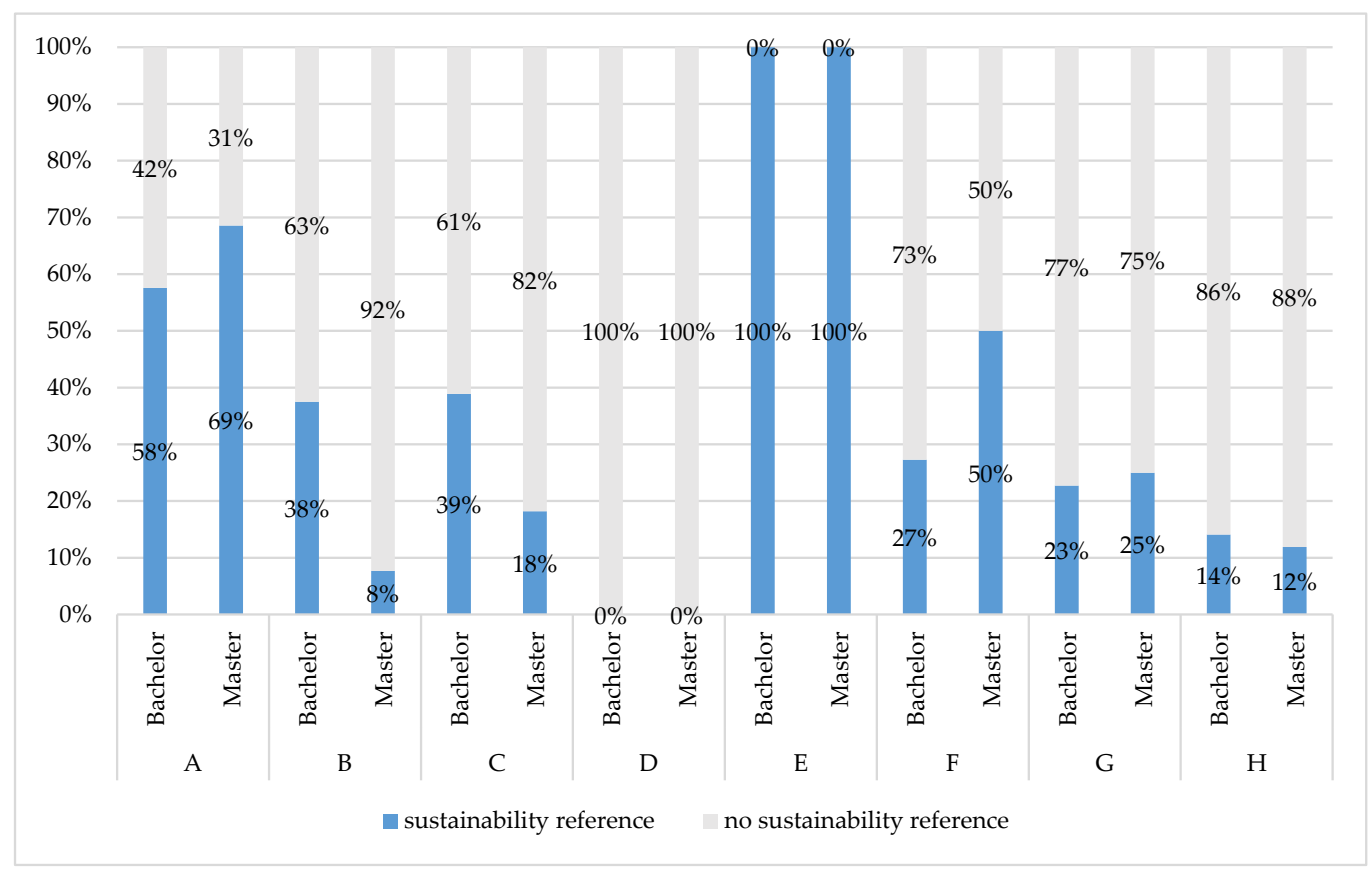

(b)

Figure 2. (a). Brandenburg study programs with and without a reference to sustainability according to the level of degree awarded: Bachelor and Master $(n=374)$; in percent. $(\mathbf{b})$. Brandenburg study programs with and without a reference to sustainability according to the level of degree awarded: Bachelors and Master $(n=374)$ according to university, A to H; in percent. 
If we consider the university-specific distribution of the study programs with a reference to sustainability according to the two levels of degree (bachelor's and master's degrees), we arrive at a different picture (see Figure $2 b$ ). At two universities ( $G$ and $H$ ), there is approximately the same number of bachelor's and master's study programs with a reference to sustainability. At two universities (B and C), the reference to sustainability is more pronounced in the bachelor's study programs. At two further universities (A and F), it is more pronounced in the master's study program.

\subsection{Type of Degree Awarded for the Study Programs}

Sustainable development requires all academic disciplines. In order to address the question as to whether the reference to sustainability is more pronounced in the study programs of certain disciplines than of others, the data was analyzed with regard to the types of degree. Firstly, all types of study under- and post-graduate degrees were identified that are being offered throughout the state (thirteen types of degrees). In the presentation of results, bachelor and master's study programs have been grouped according to the respective type of degree awarded, leaving us with seven types of degrees (see Table 4).

Table 4. Brandenburg study programs with and without a reference to sustainability according to the type of degree, i.e., Bachelor/Master (grouped together) of Arts, of Education, of Engineering, of Fine Arts, of Laws, of Science, as well as further types of master's degrees $(n=374)$; absolute values.

\begin{tabular}{cccc}
\hline $\begin{array}{c}\text { Type of Degree } \\
\text { (Bachelor's and Master's } \\
\text { Grouped Together) }\end{array}$ & $\begin{array}{c}\text { Number of Study Programs } \\
\text { with a Reference to } \\
\text { Sustainability }\end{array}$ & $\begin{array}{c}\text { Number of Study Programs } \\
\text { without a Reference to } \\
\text { Sustainability }\end{array}$ & Total \\
\hline Bachelor/Master of Arts & 21 & 83 & 104 \\
Bachelor/Master of Education & 4 & 39 & 43 \\
Bachelor/Master of Engineering & 23 & 27 & 50 \\
Bachelor/Master of Fine Arts & 1 & 16 & 16 \\
Bachelor/Master of Laws & 62 & 75 & 17 \\
Bachelor/Master of Science & 2 & 5 & 7 \\
Further master's degrees & 113 & 261 & 374 \\
Total & & & \\
\hline
\end{tabular}

At universities in Brandenburg, it was established that, overall, the reference to sustainability is most pronounced in study programs that lead to a Bachelor's/Master of Engineering $(46 \%)$ or a Bachelor/Master of Science (45\%). With further types of master's degrees (29\%) and for a Bachelor/Master of Arts (20\%), the reference to sustainability was evident to a medium extent and in the Bachelor/Master of Education (9\%) and the Bachelor/Master of Laws (6\%), there was little evidence of a reference to sustainability. For the degree type Bachelor/Master of Fine Arts, there was no evidence of any reference to sustainability (see Figure 3).

From a purely quantitative point of view, the finding that a high number of science and engineering study programs make reference to sustainability in their curricula can be assessed as positive. Both types of degrees include a fairly large number of study programs (Bachelor/Master of Engineering with 23 study programs with a reference to sustainability and Bachelor/Master of Science with 62, Table 4). 


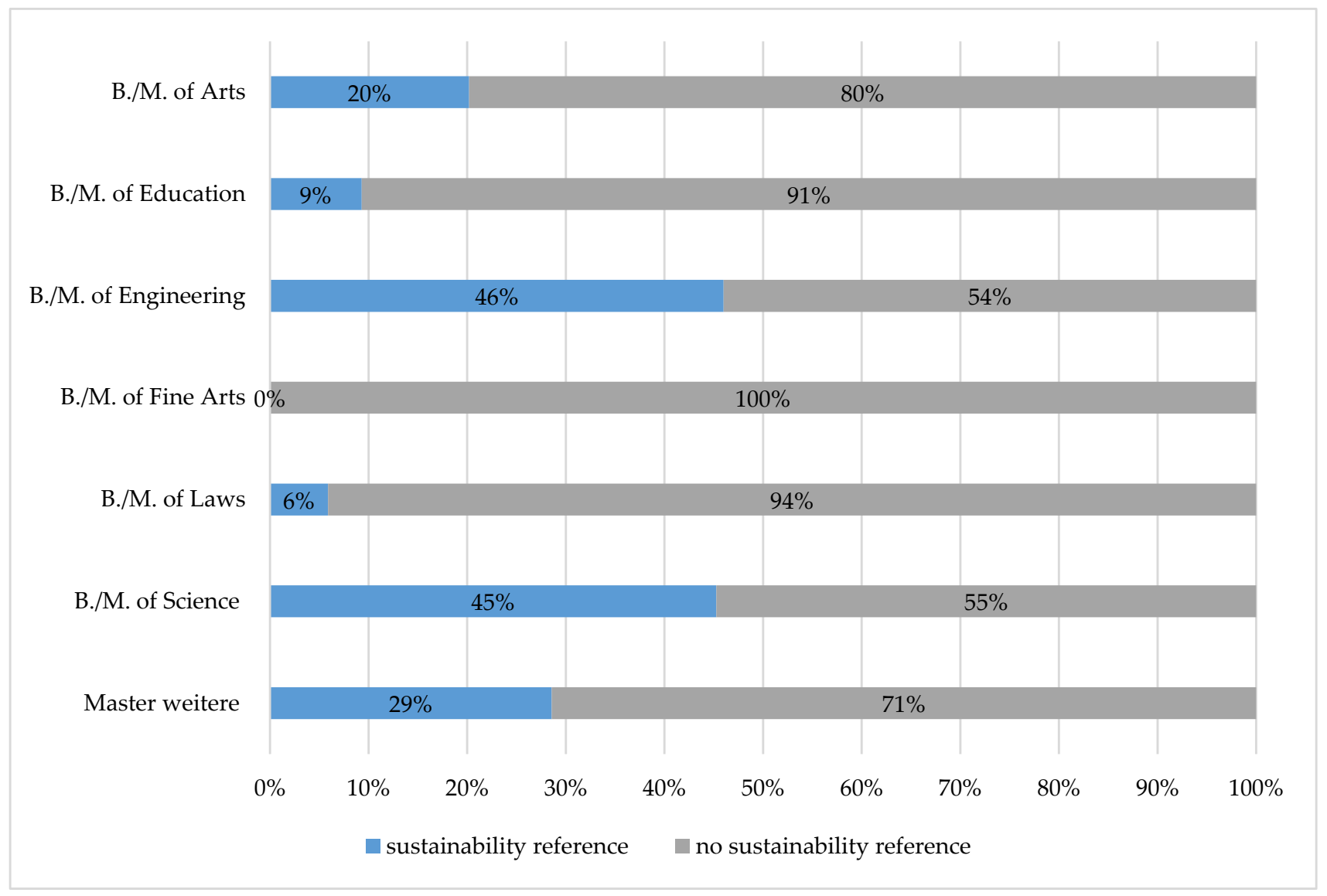

Figure 3. Brandenburg study programs with and without a reference to sustainability, according to the type of degree awarded, i.e., Bachelor/Master (grouped together) of Arts, of Education, of Engineering, of Fine Arts, of Laws, of Science, as well as further types of master's degrees $(n=374)$; in percent.

\subsection{Level at which Sustainability Is Anchored: Types of Document with a Reference to Sustainability}

Using the National Monitoring [29] as a starting point, we were interested in establishing the level of commitment that was shown to anchoring sustainability in the curricula. To follow on from the findings for Q1 (the reference to sustainability in the study programs), a differentiated analysis of the various types of documents was then undertaken. The question was asked as to the "level" at which sustainability was anchored in the curricula-at the level of study and examination regulations and/or module descriptions? This was based on the assumption that sustainability can be considered to be more strongly anchored in a study program if the subject is mentioned in both types of documents; and that this would imply more commitment to addressing the subject of sustainability.

On average, sustainability is mentioned in both the study and examination regulations and the module descriptions in $12 \%$ of Brandenburg study programs (see Figure 4). Here, the reference made to sustainability is very pronounced in comparative terms and it can therefore be assumed that there is a higher level of commitment to the subject. In a further $18 \%$ of study programs, sustainability is only mentioned in the module descriptions. Less than $0.5 \%$ of study programs showed evidence of a reference to sustainability in the study and examination regulations only. 


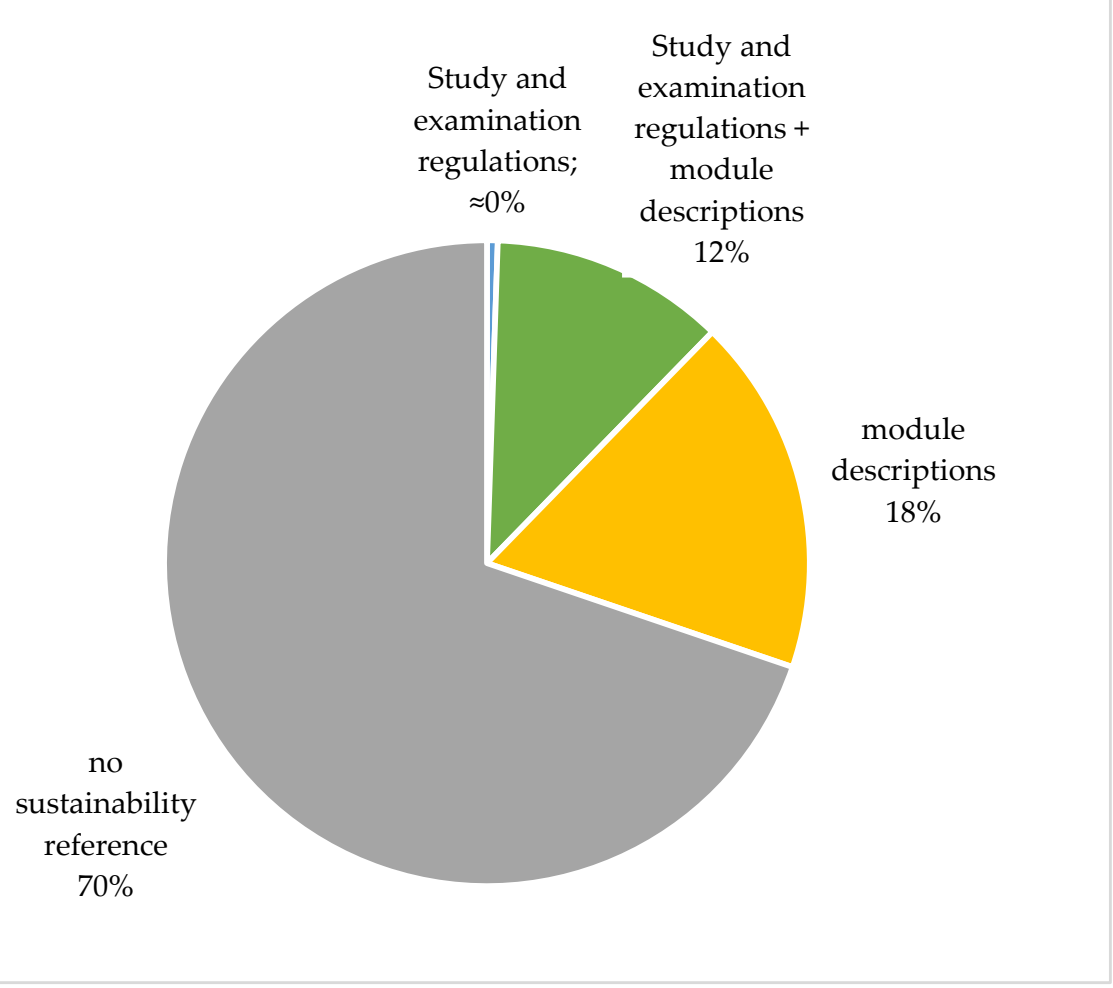

Figure 4. Reference to sustainability in the study and examination regulations and in the module descriptions of Brandenburg study programs $(n=374)$; in percent.

\subsection{Context of the Reference to Sustainability in Study and Examination Regulations}

For a more differentiated understanding of the results on the study and examination regulations, we then looked at whether "sustainability" comes up in the context of the main document or the document attachment (see Figure 5) (context meaning the section of text, i.e., the unit of analysis). A differentiation was made between strong, medium, and weak in terms of the level of representation of sustainability (cf. Table 2, V4). Of all 46 of the study and examination regulations with a reference to sustainability, sustainability was mentioned in the context of both the main document and the document attachment in $26 \%$ of cases; here, we would say that there is a strong representation of sustainability. If it is assumed that there is only a medium level of representation of the subject of sustainability where there is only evidence of a reference to sustainability in the main document, then this would apply to $37 \%$ of the study and examination regulations examined. With a further $37 \%$, sustainability was only mentioned in the context of the document attachment; here, we would say that there is a weak level of representation of the subject.

When putting these results in relation to the total number of study and examination regulations included in the study $[n=374]$, we see that sustainability is strongly anchored in only $3 \%$ of the documents, anchored to a medium extent in $5 \%$ of cases, and to a weak extent in a further $5 \%$. 


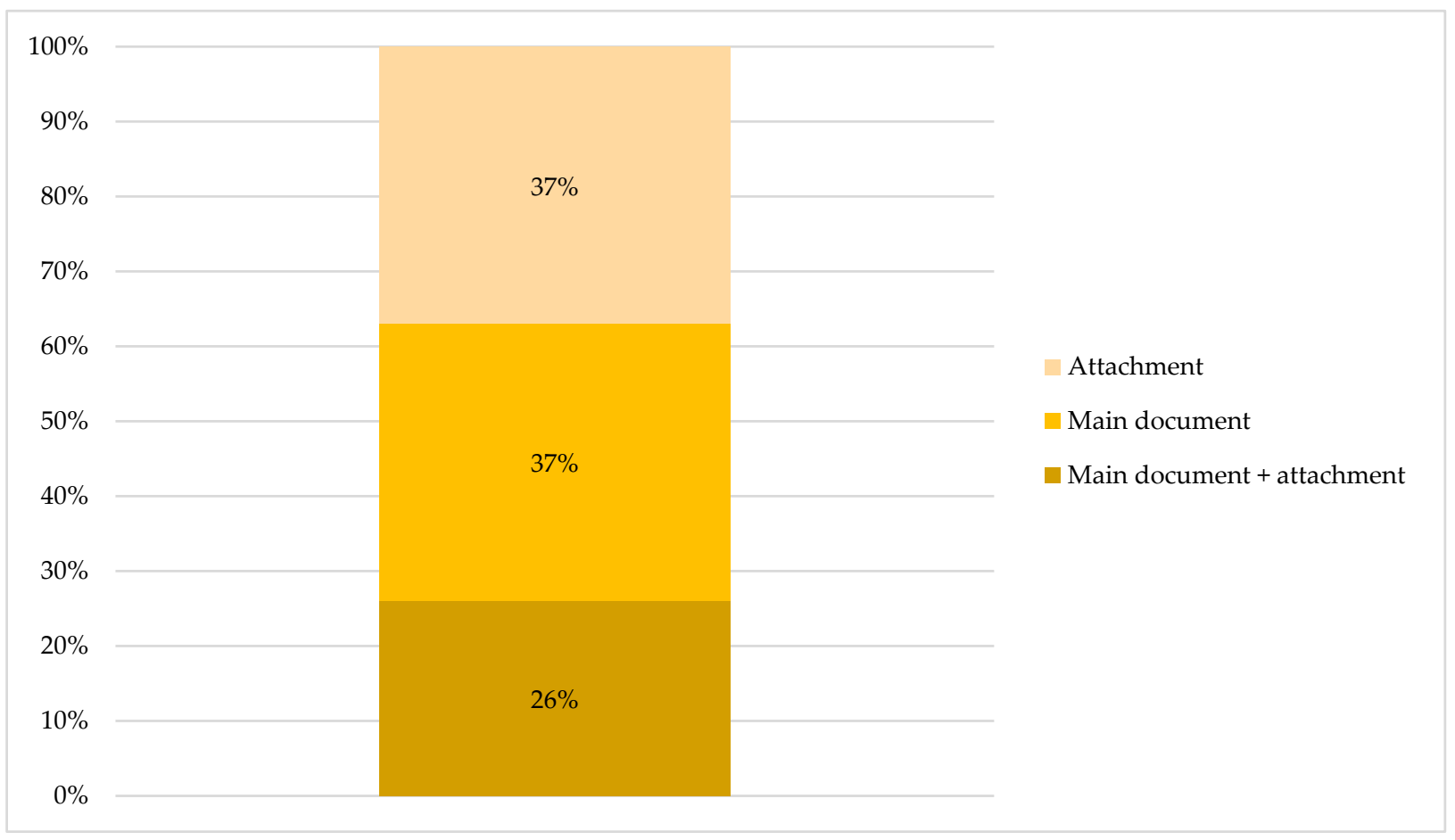

Figure 5. Context of the reference to sustainability in the study and examination regulations in Brandenburg $(n=46)$; mention of the subject in the main document and/or attachment; in percent.

\subsection{Context of the Reference to Sustainability in Module Descriptions}

A similar approach was used to achieve a more differentiated understanding of the results on the module descriptions. Across the whole of the federal state, there were 112 module descriptions that contained a reference to sustainability. The context was differentiated between the title, the goal, and the content of the module (see Figure 6). In $30 \%$ of these module descriptions, "sustainability" is mentioned in the title, the goals, and the content of the module; here we would say that there is a strong level of representation of the subject. It is assumed that there is a medium level of representation of the subject of sustainability in the document if it is mentioned in two out of three categories (title and goal, or title and content, or goal and content). In accordance with this assumption, it was observed that there is a medium level of representation of sustainability in $34 \%$ of the module descriptions. In $35 \%$ of the module descriptions, there is a rather weak level of representation of the subject, because sustainability is only mentioned in the context of either the goals or the content of the module. And in just one percent of module descriptions, sustainability is only mentioned in the context of the title for the module.

When looking at these results in relation to the total number of module descriptions included in the study [ $n=374]$, we see that sustainability is strongly anchored in $9 \%$ of all module descriptions, anchored to a medium extent in $10 \%$, and to a weak extent in a further $10 \%$ of cases. 


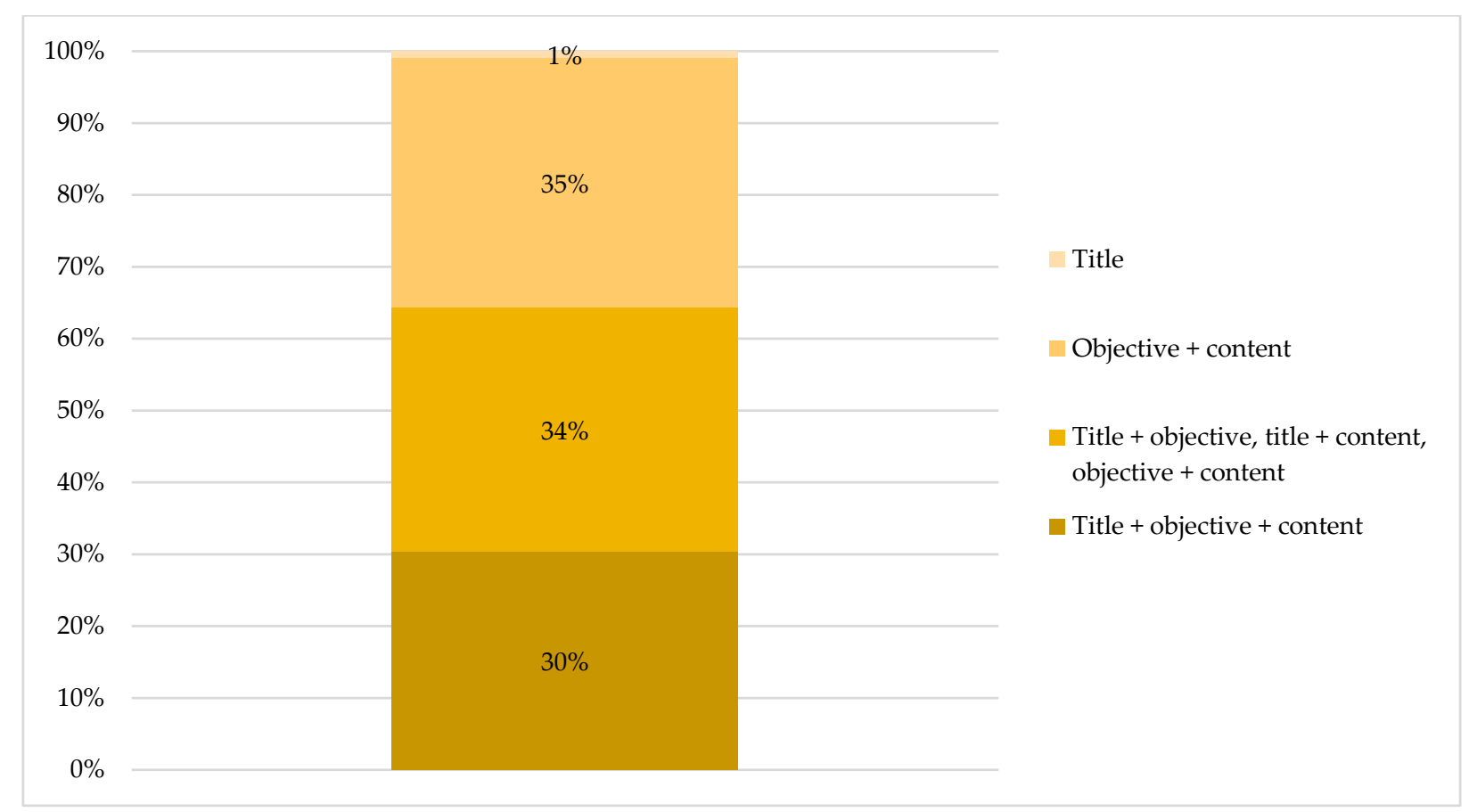

Figure 6. Context of the reference to sustainability in module descriptions in Brandenburg $(n=112)$; mention of sustainability in the title, goal, and/or content of the module; in percent.

\subsection{Answering the Research Question}

The research question and its sub-questions can be answered as follows: Almost a third of the study programs of the federal state show evidence of a reference to sustainability in their curricula (Q1). This was evident to an equal extent between bachelor's and master's degrees (Q2). There was a higher than average incidence of references to sustainability in science and engineering-based study programs in comparison to other types of degrees (Q3). In $12 \%$ of the study programs in the federal state, it is possible to say that there is a strong commitment to sustainability in the curricula (through the anchoring of the subject in both types of document examined, Q4). However, sustainability is only strongly anchored in study and examination regulations in 3\% of cases (Q5), and in only $9 \%$ of module descriptions (Q6).

\section{Discussion}

To follow, the findings on Q1-6 are being discussed in more detail (discussion of results). After pointing out the scientific value added through this study with regard to both its academic and its application-focused research interest, methodical aspects (study limitations) such as opportunities for future research will be discussed.

Discussion of results: In order to be able to rank and contextualize the cross-university results on the reference made to sustainability in approx. a third of study programs (see Chapter 3.1.) in a national context, it is recommendable to conduct comparable studies in other federal states. With regard to achieving the university policy goal of "Implementing ESD in (existing) curricula" [1] and the corresponding expansion of study programs, the working group "Sustainability in Brandenburg Universities" recently agreed on a series of cross-university measures (assistance with the integration of sustainability into module descriptions, capacity-building for staff responsible for the study programs and for quality managers) [47].

With regard to the further anchoring of sustainability in the curricula, there is potential at some individual universities to expand their offer of study programs in subjects related to sustainable development. Whether and how the universities decide to proceed is dependent on a range of factors (including the profile of the university, the university 
development plans, the timeframe and window of opportunity for curricular reforms, etc.). Stimulus may possibly be provided by the results on the level of degree (Q2) and the type of degree (Q3); also, with a view to the strategic alignment of the universities in the region [33,34,88]. In addition, the implementation patterns of Fiselier et al. [24] could be a helpful continuation for universities.

The cross-universityBellina findings that, across the federal state, sustainability is anchored to the same extent in study programs that lead to both a bachelor's and a master's degree (3.2. Level of degree, different e.g., Aleixo et al. 2020 [23]) are of interest with regard to the role of universities in regional development: as universities provide the necessary academic skilled workers for the regional market [32], this means that specialist competencies that are relevant to sustainability find their way to the same extent into the professions that are taken up by skilled workers with a first-level degree (bachelor's) as those taken up by those with a more a specialized education (master's) (As there is a comparable number of study programs (absolute numbers), it can be assumed here that the results will also be highly significant in quantitative terms.). With regard to the strategic future development of the universities, university-specific results are of more interest and more meaningful: depending on the organization-specific findings, universities may set themselves the goal of expanding their offer of degree courses in subjects related to sustainability in terms of both undergraduate (bachelor's) and post-graduate (master's) study programs, depending on which areas have to date shown evidence of weaker anchoring of sustainability, or the desired focus of the university's profile.

With regard to the strategic development of universities (cross-university and universityspecific), the findings on the type of degree (Chapter 3.3) with and without reference to sustainability would seem to be of interest. We were interested in finding out whether sustainability was predominantly addressed by certain disciplines. The classification criteria "Type of degree", which has been selected here, results in the allocation of study programs within the same discipline (e.g., educational sciences) to various different types of degree: an education degree may lead to a Bachelor/Master of Education or to a Bachelor/Master of Arts. A further, more differentiated option for systemization would be, for example, to assign the study programs to subject groups, as is done in the "Higher Education Compass" information portal. These groups could be: 1. Agricultural sciences and forestry, 2. Social studies and social sciences, 3. Engineering, 4. Art, Music, Design, 5. Teacher training, 6. Mathematics, Science, 7. Medicine, Health Sciences, 8. Public Administration, 9. Linguistics and Cultural Studies, and 10. Economic science, Law [89]. Categorization according to other criteria would have brought further methodological challenges, in particular with interdisciplinary study programs as it could have resulted in multiple allocations. The grouping system for the study programs used here, using the criterion "Type of degree", allows unequivocal categorization.

While there is an above-average incidence of references to sustainability in science and engineering-based study programs (see as well the results of the case study of ten engineering programs of Sánchez-Carracedo et al. 2019 [26]), the results point to unused potential in terms of the anchoring of (E)SD in the study programs of those types of degree that have up until now contained no or only very little reference to sustainability. This also applies with a view to an understanding of the Brandenburg universities as "society's engines for innovation" [43] as well as the federal state and university policy goal of enabling "students and graduates as key shapers of sustainable development" [2]. In order for students to be able to play an active role in shaping sustainable development, they need to be provided with sufficient opportunities to develop the specialist competencies required to shape the future in a more sustainable way. This requires wide-scale anchoring of (E)SD in university curricula in all disciplines that are of strategic relevance to wide-ranging sustainable regional development.

There is a particular potential for development in the anchoring of sustainability in the Bachelor/Master of Arts and the Bachelor/Master of Education. With a total of 104 study programs, the Bachelor/Master of Arts carries particular weight in quantitative terms 
and covers a wide spectrum of different disciplines (Economic Science, Historiography and Political Science, Linguistics, Communication Studies and Informatics, Social Science, Cultural Studies and Religious Studies, Fine Art and Media Studies, Design, Architecture and Town Planning). The Bachelor and Master of Education are of strategic relevance as they have an impact across the entire federal state in the area of school education, in particular through teacher training degrees (concentrated at one university) [see also 27, 28 for comparable findings and recommendations form international research]. The situation is similar with the Bachelor/Master of Laws (a total of 17 study programs at two universities) and the Bachelor/Master of Fine Arts (a total of 16 study programs at one university) as the graduates of these programs play a key role in society. There is an opportunity in the training of lawyers to put the complex principle of sustainability into concrete terms and to operationalize it in legal practice. Artists and those working in the field of culture are not only able to establish sustainable production techniques; they also develop and create narratives for sustainability and play a central role in helping to shape society's perception of sustainability.

The prerequisite for further, subject-specific coordinated anchoring of sustainability in the curricula is that, in each individual case, a meaningful connection can be created to the content of the study program and that the university or the faculty in question have given their fundamental approval and are in support of the process. In response to the particular need for the integration of sustainability in certain disciplines, there are already nationwide programs and networks in place to support university development; for example the training program "Lehr ${ }^{\mathrm{N}}$ " in Humanities and Social Science [90] and the LeNA network for teacher training in the German-speaking area [91]. It would be desirable for such offers of support to be set up (and expanded) and for them to be tailored to the specific needs of the federal state and the universities.

The results on the level and context of the reference made to sustainability in the various types of document examined (3.4-3.6) can provide indications as to where stronger and more binding commitment could be shown to the anchoring of sustainability in the curricula.

If we look at the level at which sustainability is anchored in the curricula (via analyzing the type of document with a reference to sustainability) in cross-university terms (Chapter 3.4), it can be concluded that a strong commitment to sustainability in the curricula is present in $12 \%$ of study programs. This could certainly be improved upon by further anchoring sustainability in both types of documents (module descriptions and study and examination regulations). Another $18 \%$ of all study programs mention sustainability only in their module descriptions. In order to raise the level of commitment of these study programs to the subject of sustainability, it is recommended to include sustainability in the associated study and examination regulations. A further $70 \%$ of study programs do not show any mention of sustainability. In these cases, it might be recommended to start with the reform of module descriptions, since these reform processes are more flexible in time and formal procedure. Once a study program has established a topic in its module description, the groundworks are laid for including in into the study and examination regulations in the (re)accreditation of the study program. Under $0.5 \%$ of study programs make reference to sustainability in the study and examination regulations only, and not in the corresponding module descriptions. This striking quantitative result might be explained the following way: If a topic is mentioned in a study and examination regulation, it is usually also addressed in the module description since the module description is the more extensive document, explaining the content of modules of a study program. It is unusual that a topic is being mentioned in the study and examination regulation, but not in the module description, hence this irregular quantitative result.

The analysis of the context in which sustainability appears in the study and examination regulations (Chapter 3.5, context: main document, attachment) showed that there is "room for improvement": If we consider the results in relation to the total number of study programs included in the survey, we see that sustainability is only strongly anchored in $3 \%$ 
of the study and examination regulations (anchored to a medium extent in $5 \%$ of cases and to a weak extent in a further $5 \%$ ). Changes in the level of study and examination regulations are more difficult to implement since they depend on special competencies of responsible staff and windows of opportunity in (re)accreditation processes. This is why capacitybuilding measures are required that enable staff responsible for the (re)accreditation of study programs to systematically include (E)SD in study and examination regulations (e.g., special representatives at faculty/department level or for the whole university). Such measures have been sparked in individual cases, for example, by the project HochN [16]. For systematic improvement the state level, it is recommended to develop local, long-term supporting structures.

If we look at the context in which sustainability appears in the module descriptions (Chapter 3.6, context: title, goal, content) in relation to the total number of study programs, we found that the subject is strongly anchored in 9\% of all module descriptions (anchored to a medium extent in $10 \%$ of cases and to a weak extent in a further $10 \%$ ). Again, capacity-building measures are recommended in order to strengthen the role and systematic anchoring of sustainability in module descriptions. As mentioned above, the working group "Sustainability in Brandenburg Universities" [1,47] recently agreed on the measures to provide assistance in the integration of sustainability into module descriptions. With regard to the applied research method, one needs to bear in mind, that module descriptions show structural differences in form, length, and design (see also 14). In the present study, we consider the quantitative findings to be very reliable; however, these specifics need to be considered when applying the method in future studies. Additionally, including and strengthening sustainability in module descriptions needs to take the structural specifics of each study program and university into account.

In accordance with these results, there is potential for development, in particular, if we assume that "extensive anchoring of (E)SD is [ ... ] found where there is a high level of commitment in the modules of the respective study and examination regulations and module descriptions" [29] (p. 219). Based on our findings we are not able to draw conclusions with regard to the other condition mentioned in the National Monitoring, a "comprehensive offer of modules in the study programs" (ibid.). Although these were indeed recorded where possible, they were not evaluated in quantitative terms. In the future, this could be of interest for those study programs that are keen on making qualitative improvements to their offer of ESD-focused degrees [16]. At this point, the further use of the results for constructive purposes can best be done in a university-specific context.

Furthermore, it is to be assumed that there is strong anchoring of ESD in competencybased and practice-oriented learning settings $[3,10,16,32,35,40,46,54]$. The systematic identification of these learning settings throughout all universities at the state level will require further research. Our study can offer a database and a starting point for such research by looking at those study programs dealing with sustainability. However, one needs to take into consideration that a merely quantitative survey of these learning settings is not possible. With regard to stronger anchoring (E)SD in the curricula, it would therefore appear to be expedient to create offers to support those responsible for the study programs with the further development of the curricula keeping in mind learning settings such as these (accompanied by offers of coaching and higher education didactic seminars for teaching staff). In this way, important competencies can be fostered at the universities, in terms of both staff training and the development of organizational competencies, which will enable all (present and former) members of the university to play a part in shaping the regional process of transformation towards sustainability, both in individual terms and as an institution.

In accordance with the research framework, the results do not provide information on how universities specifically influence regional developments. However, the results can help to clarify the role of universities in regional sustainability transformation and can provide starting points for the strategic orientation of universities [34,88]. With the equally strong anchoring of sustainability in bachelor's and master's degree programs, skills in the 
field of sustainability can be assumed among both undergraduate and more specialized professionals, which is a basic prerequisite for sustainable regional development. In order to promote a regional sustainability transformation, it is necessary to anchor Higher Education for Sustainable Development in the curriculum across all disciplines. How the development of competencies for sustainable development will reflect in future regional actors and concretely in regional sustainability projects remains to be investigated [33]. For further university development and the strategic orientation of Brandenburg's universities as drivers for regional sustainability transformation, these results and the further starting points for comprehensive ESD monitoring in Brandenburg provide a basis for orientation.

Scientific value-added: The results of this study contribute at the federal state level (Brandenburg) to the National Monitoring of the anchoring of ESD in the area of higher education [29]. The method used was transferred to the federal state level and an excerpt (document analysis of curricula) was examined in depth. Firstly, this means that we now have, for the first time, a set of comprehensive findings on the status in terms of the anchoring of sustainability in the curricula of a federal state (Brandenburg). Secondly, the methodological approach used is suitable for use in other federal states. The adaptations undertaken here complete the results of the National Monitoring to the extent that all the universities and study programs of a federal state were included (Q1) and, as well as the undergraduate bachelor's study programs, the more specialized study programs of the master's degree were also included in the study (Q2). Furthermore, we now have a comprehensive and differentiated set of results on the various fields of study (and types of degree) in which sustainability is anchored (Q3). The differentiated examination of the level and context of the reference to sustainability in the various types of document (Q4-6) can also provide indications as to how extensively the theme is anchored in the curriculum and with what level of commitment.

Furthermore, the results can provide stimuli for the further development of the universities in Brandenburg and can support the universities in their strategic alignment as active drivers of sustainable regional development. The working group on the anchoring of sustainability in the Brandenburg universities [1] has suggested that Brandenburg could be further developed as a location for a diverse range of sustainability-related degrees [47]. With this vision in mind, cross-university and university-specific measures could be developed to help to anchor sustainability in the curricula, and the results of this study can make a useful contribution in this respect (similarly as, for example, the EDINSOST project [26-28,92]).

Study limitations: It should be pointed out that the results of this study do not allow any statements to be made on either the sustainability-related teaching practice at the universities [16] or on sustainability management in further areas of activity of the universities (such as in governance, research, transfer or operation). There are countless examples of good practice and innovative approaches in these areas that are not portrayed using the study design that has been selected here, but which are of key importance for the sustainable development of the university and for sustainable regional development.

In this study, we worked with tightly defined search terms that could be clearly demarcated. It is to be assumed that some study programs may not have been included because, although they deal with sustainability, they did not describe it in precisely these terms. It is possible that the reason for the more pronounced level of reference to sustainability in engineering and science-based study programs was the fact that the German (and European) understanding of sustainability places the focus on the environmental aspects of the subject $[10,22]$. Topics covered within the theme of sustainability tend to be environmental topics, such as climate protection. For one thing, people are not yet sufficiently aware of the social and economic dimensions of sustainable development (in accordance with this, there could perhaps be more focus on the development of an integrated understanding of the three dimensions of sustainability) [93]. For another, it is possible that subjects such as health, education, gender equality, and decent working conditions are even more seldom seen in the context of sustainable development. The latter allows us to assume, by 
implication, that in many study programs, students are in fact already addressing subjects and issues relating to sustainable development, but these topics are not (yet) being dealt with in reference to the concept of sustainability.

Future research: In order to obtain a more complete picture as to which study programs show evidence of close links to the concept of sustainability or address the subject of sustainability, future studies could try expanding the analysis to further search terms. These would need to represent topics relating to sustainable development, such as health, gender equality, climate protection, etc. Narrowing down these topics and terms will certainly present a challenge, but the topics formulated in the SDGs could perhaps offer a good starting point $[22,23]$. On the meta-level of the educational concept, the original and the expanded set of terms used in the National Monitoring [29,31] could be made use of again and expanded to include further concepts.

The documents analyzed in the present study contain rich information which can be further analyzed, e.g., by using exploration or correlation analysis in order to detect trends of the content of these documents. Interesting questions would be: Can we detect correlations between certain variables (e.g., V2 level of degree and V3 type of degree); which topics of sustainable development are being addressed (e.g., such as health, gender equality, climate protection, etc.) and in which context; is sustainability mentioned in the context of certain learning settings (e.g., practice-based settings, field trips, etc.); do sustainability studies take place in compulsory or elective modules, in introductory or advanced modules, in disciplinary or inter-/transdisciplinary settings, etc. [15,16]. Furthermore, it would be interesting to expand the analysis by including other document types (e.g., course catalogs, websites, etc.).

Regarding the successful implementation and further integration of (E)SD into higher education curricula at the state level, it would be very promising to further investigate this studies' findings against the newest international results on drivers and barriers of implementing sustainability curricula [94]. If looking at the state of implementation of ESD in Higher Education in the state of Brandenburg beyond the curricular level (e.g., analyzing mission statements, capacity-building opportunities, etc.), it would be highly desirable to adapt the method of the National Monitoring on ESD implementation to specific structures at the state level [29-31].

\section{Conclusions}

With this study, we now have, for the first time, a set of comprehensive findings on how the issue of sustainability is anchored in higher education curricula of a federal state (Brandenburg). These can contribute to systematic and more wide-scale monitoring on a national level. The research approach in this study was developed out of the National Monitoring on Higher Education for Sustainable Development. The analysis of curricular documents was transferred from the national to the state level and, therefore, is suitable for future application in other federal states. The adaptions that were undertaken in this study relate to the collection of the total amount of empirical units and their in-depth analysis. By looking at all study programs at the state level, all curricular documents available from the two document types-study and examination regulations and module descriptions-were collected and analysed according to six variables.

Moreover, this study has a very application-oriented interest. Universities and ministries of the state of Brandenburg, Germany have committed to both sustainable regional development and to permanently integrating (Education for) Sustainable Development into the higher education system at the state level. The working group for the anchoring of "Sustainability at Brandenburg Universities" has suggested the further development of the state as a location for a diverse range of sustainability-related degrees. The role of sustainability in higher education curricula is crucial to future regional development, with students and alumni being the academic skilled professionals that shape the region in the future. All (1) study programs were analyzed regarding the appearance of the term sustainability in their curricular documents. The analysis of the (2) level of degree showed that sustain- 
ability is anchored to an equal extent in both bachelor's and master's study programs. With the equally strong anchoring of sustainability in bachelor's and master's degree programs, one can assume that both undergraduate and more specialized professionals at the graduate level have knowledge on sustainability, which is a basic prerequisite for sustainable regional development. Given the university-specific differences of these results, recommendations for the future strategic development of respective universities would depend on which level of degree has, to date, more potential of anchoring sustainability, and on the desired focus of the university's profile. The analysis of the (3) type of degree showed that sustainability is anchored to an above-average extent in study programs in the fields of science and engineering. Regional sustainability transformation requires (Higher Education for) Sustainable Development in the curriculum across all disciplines. Therefore, disciplines and subjects of Humanities and Social Science have the potential to relate their curricular contents more strongly to the concept of sustainability. This applies especially to Bachelor/Master of Arts and of Education due to their quantitative weight and strategic relevance in the region, as well as to Bachelor/Master of Laws and Fine Arts. The differentiated examination of the level and context of the reference to sustainability in the various types of documents shows areas of opportunity for strengthening the topic within the curricular documents. The analysis of the (4) level of anchoring of sustainability in the curricula showed that $12 \%$ of study programs in the federal state make reference to sustainability in both document types. This is considered to be a strong commitment to sustainability at the curricular level. There is potential for strengthening the commitment for that $18 \%$ of study programs that refer to sustainability only in their module descriptions by also including the topic into the study and examination regulations. For the other 70\% of study programs, integrating sustainability in the module descriptions seems to be a recommendable first step. The specific examination of each of the two document types indicates how extensively sustainability is anchored in the curriculum. The analysis of the (5) context in study and examination regulations showed that sustainability is strongly anchored in 3\% of these documents at the state level (sustainability reference in both main document and attachment). The analysis (6) context in module descriptions showed that sustainability is strongly anchored in $9 \%$ of module descriptions (sustainability reference in both title, goal, and content of the module description). These findings indicate that capacity-building measures would be recommendable for staff at those study programs that want to anchor sustainability more extensively in their curricular documents; e.g., staff responsible for (re)accreditation of study programs or for the (further) development of module descriptions.

Universities in the state of Brandenburg have many more sustainability-related activities at the curricular level and beyond that are not captured by this study and which can be the subject of future research. The findings of the present study can be a starting point for cross-university and university-specific measures for further anchoring sustainability in the curricula. They can support the universities in clarifying their role in regional sustainability transformation and in their strategic alignment as active drivers of sustainable regional development.

Author Contributions: Conceptualization, J.M.K. and H.M.; methodology, J.M.K. and H.M.; software, J.M.K., validation, J.M.K. and H.M.; formal analysis, J.M.K. and H.M.; investigation, J.M.K. and H.M.; resources, J.M.K.; data curation, J.M.K.; writing-original draft preparation, J.M.K., J.R. and H.M.; writing-review and editing, J.M.K., J.R. and H.M.; visualization, J.M.K.; supervision, H.M.; project administration, J.M.K.; funding acquisition, H.M. All authors have read and agreed to the published version of the manuscript.

Funding: This research received no external funding.

Institutional Review Board Statement: Not applicable.

Informed Consent Statement: Not applicable.

Data Availability Statement: Data is stored an HNE Eberswalde and can be provided upon request. 
Acknowledgments: We would like to thank the representatives of the Sustainability at Brandenburg Universities working group as well as the representatives of the Brandenburg State Rectors' Conference for their contributions with regard to the validation and the discussion on methods and results, as well as the participants of the FU Spring Campus Workshop for their contributions to the discussion on methods and results. Furthermore, we thank Mandy Singer-Brodowski and Marie Weiß for their valuable input during the review process. We would like to extend our particular thanks to Bettina Bloem-Trei for the huge amount of support she gave us with data collection, to Simon Rimkus for his support with validation and Christiane Villain for her support with visualization.

Conflicts of Interest: Dual role of authors in the coordination office for Sustainability in Higher Education Institutions in the State of Brandenburg: The office carries out accompanying research like the present study and supports universities in the development of cross-university and universityspecific measures for the anchoring of sustainability in study programs.

\section{References}

1. Ministerium für Wissenschaft, Forschung und Kultur Brandenburg [Ministry for Science, Research and Culture for Brandenburg] and the Eight Public Universities of the Federal State. Higher Education Contracts 2019-2023. Available online: https://mwfk. brandenburg.de/mwfk/de/wissenschaft/rechtliche-grundlagen-zentrale-dokumente/ (accessed on 27 November 2020).

2. MLUL-Ministerium für Ländliche Entwicklung, Umwelt und Landwirtschaft des Landes Brandenburg [Ministry for Rural Development, Environment and Agriculture of the Federal State of Brandenburg], Department for Press and Public Relations. Sustainability Strategy for the Federal State of Brandenburg. Updated 2019. Available online: https://mluk.brandenburg.de/ sixcms/media.php/9/Fortschreibung-Nachhaltigkeitsstrategie-BB.pdf (accessed on 27 November 2020).

3. United Nations Educational, Scientific and Cultural Organization (UNESCO). Education for Sustainable Development. A Roadmap. \#ESD for 2030. Available online: https://unesdoc.unesco.org/ark:/48223/pf0000374802 (accessed on 13 December 2020).

4. Sachs, J.D.; Schmidt-Traub, G.; Mazzucato, M.; Messner, D.; Nakicenovic, N.; Rockström, J. Six Transformations to achieve the Sustainable Development Goals. Nat. Sustain. 2019, 2, 805-814. [CrossRef]

5. United Nations General Assembly 70/1. Transforming Our World: The 2030 Agenda for Sustainable Development. Available online: https://sustainabledevelopment.un.org/content/documents/21252030\%20Agenda\%20for\%20Sustainable\%20 Development\%20web.pdf (accessed on 11 December 2020).

6. National Platform: Education for Sustainable Development; Federal Ministry of Education and Research. National Action Plan on Education for Sustainable Development. Available online: https://www.bmbf.de/files/BMBF_NAP_BNE_EN_Screen.pdf (accessed on 11 December 2020).

7. Hochschulrektorenkonferenz (HRK) [German Rectors' Conference]. For a Culture of Sustainability. Recommendations of the 25th HRK General Assembly Held on 6 December 2018. Available online: https:/ / www.hrk.de/positionen/beschluss/detail/fuereine-kultur-der-nachhaltigkeit/ (accessed on 13 December 2020).

8. United Nations Educational, Scientific and Cultural Organization (UNESCO). Framework for the Implementation of Education for Sustainable Development (ESD) beyond 2019. Available online: https://www.unesco.de/sites/default/files/2020-04/40\%2 0C\%2023\%20ESD.pdf (accessed on 13 December 2020).

9. Thomas, I. Challenges for implementation of education for sustainable development in higher education institutions. In Routledge Handbook of Higher Education for Sustainable Development, 1st ed.; Barth, M., Michelsen, G., Rieckmann, M., Thomas, I., Eds.; Routledge: London, UK, 2016; pp. 55-71. ISBN 978-0-41572-730-3.

10. Krah, J.M. Partizipative Hochschulbildung für Nachhaltige Entwicklung. Implementation und Institutionalisierung in Mexiko und Deutschland [Participatory Higher Education for Sustainable Development. Implementation and Institutionalization in Mexico and Germany]. Ph.D. Thesis, Ludwigsburg University of Education, Ludwigsburg, Germany, 2018.

11. Lozano, R.; Young, W. Assessing sustainability in university curricula: Exploring the influence of student numbers and course credits. J. Clean Prod. 2013, 49, 134-141. [CrossRef]

12. Lozano, R.; Ceulemans, K.; Alonso-Almeida, M.; Huisingh, D.; Lozano, F.J.; Waas, T.; Lambrechts, W.; Lukman, R.; Hugé, J. A review of commitment and implementation of sustainable development in higher education: Results from a worldwide survey. $J$. Clean Prod. 2015, 108, 1-18. [CrossRef]

13. Wals, A.E.J. A Mid-DESD Review. J. Educ. Sustain. Dev. 2009, 3, 195-204. [CrossRef]

14. Wals, A.E.J. Sustainability in higher education in the context of the UN DESD. A review of learning and institutionalization processes. J. Clean Prod. 2013, 62, 1-8. [CrossRef]

15. Rusinko, C.A. Integrating sustainability in higher education: A generic matrix. Int. J. Sustain. High. Educ. 2010, 11, 250-259. [CrossRef]

16. Holm, T.; Sammalisto, K.; Grindsted, T.S.; Vuorisalo, T. Process framework for identifying sustainability aspects in university curricula and integrating education for sustainable development. J. Clean Prod. 2015, 106, 164-174. [CrossRef] 
17. Bellina, L.; Tegeler, M.K.; Müller-Christ, G.; Potthast, T. Education for Sustainable Development (ESD) in Higher Education Teaching (Beta Version). Available online: https://www.hochn.uni-hamburg.de/-downloads/handlungsfelder/lehre/hoch-nleitfaden-bne-in-der-hochschullehre.pdf (accessed on 13 December 2020).

18. Molitor, H. Education for sustainable development. In Humans in the Global Ecosystem. An Introduction to Sustainable Development; Ibisch, P.L., Molitor, H., Conrad, A., Walk, H., Mihotovic, V., Geyer, J., Eds.; Oekom Verlag: Munich, Germany, 2019 ; pp. 333-350. ISBN 978-3-96238-117-2.

19. Barth, M.; Thomas, I. Synthesising case-study research-Ready for the next step? Environ. Educ. Res. 2012, 18, 751-764. [CrossRef]

20. Fien, J. Advancing sustainability in higher education. Issues and opportunities for research. Int. J. Sustain. High. Educ. 2002, 3, 243-253. [CrossRef]

21. Weiß, M.; Barth, M. Global research landscape of sustainability curricula implementation in higher education. Int. J. Sustain. High. Educ. 2019, 20, 570-589. [CrossRef]

22. Hernandez, P.M.; Vargas, V.; Paucar-Cáceres, A. Education for Sustainable Development: An Exploratory Survey of a Sample of Latin American Higher Education Institutions. In Implementing Sustainability in the Curriculum of Universities. Approaches, Methods and Projects; Filho, W.L., Ed.; Springer International Publishing: Basel, Switzerland, 2018; pp. 137-154. ISBN 978-3-319-70281-0.

23. Aleixo, A.M.; Azeiteiro, U.M.; Leal, S. Are the sustainable development goals being implemented in the Portuguese higher education formative offer? Int. J. Sustain. High. Educ. 2020, 21, 336-352. [CrossRef]

24. Fiselier, E.S.; Longhurst, J.W.S.; Gough, G.K. Exploring the current position of ESD in UK higher education institutions. Int. J. Sustain. High. Educ. 2017, 19, 393-412. [CrossRef]

25. Novo-Corti, I.; Badea, L.; Tirca, D.M.; Aceleanu, M.I. A pilot study on education for sustainable development in the Romanian economic higher education. Int. J. Sustain. High. Educ. 2018, 19, 817-838. [CrossRef]

26. Sánchez-Carracedo, F.; Moreno-Pino, F.M.; Sureda, B.; Antúnez, M.; Gutiérrez, I. A Methodology to Analyze the Presence of Sustainability in Engineering Curricula. Case of Study: Ten Spanish Engineering Degree Curricula. Sustainability 2019, 11, 4553. [CrossRef]

27. Muñoz-Rodríguez, J.M.; Sánchez-Carracedo, F.; Barrón-Ruiz, Á.; Serrate-González, S. Are We Training in Sustainability in Higher Education? Case Study: Education Degrees at the University of Salamanca. Sustainability 2020, 12, 4421. [CrossRef]

28. Solís-Espallargas, C.; Ruiz-Morales, J.; Limón-Domínguez, D.; Valderrama-Hernández, R. Sustainability in the University: A Study of Its Presence in Curricula, Teachers and Students of Education. Sustainability 2019, 11, 6620. [CrossRef]

29. Etzkorn, N.; Singer-Brodowski, M. Anchoring Education for Sustainable Development in higher education. In Wegmarken zur Transformation, 1st ed.; [Milestones on the Way to Transformation]; Brock, A., de Haan, G., Etzkorn, N., Singer-Brodowski, M., Eds.; Verlag Barbara Budrich: Berlin, Germany, 2018; ISBN 978-3-8474-2147-4.

30. Holst, J.; von Seggern, J. Education for Sustainable Development (ESD) in Universities: Structural Anchoring in Laws, Agreed Goals and Documents of Self-Administration. Available online: https:/ /www.ewi-psy.fu-berlin.de/einrichtungen/weitere/ institut-futur/Projekte/Dateien/2020_BNE_Dokumentenanalyse_Hochschule.pdf (accessed on 13 December 2020).

31. Holst, J.; Brock, A.; Singer-Brodowski, M.; de Haan, G. Monitoring Progress of Change: Implementation of Education for Sustainable Development (ESD) within Documents of the German Education System. Sustainability 2020, 12, 4306. [CrossRef]

32. Reimer, M.; Miosga, M. The future role of universities in the modern knowledge economy and their tasks within the context of the overall transformation towards sustainability. In Regionale Nachhaltigkeitstransformation-Wissenschaft, Wirtschaft und Zivilgesellschaft im Dialog; [Regional Transformation towards Sustainability-Academia, the Economy and Civil Society in Dialog]; Hafner, S., Miosga, M., Eds.; Oekom Verlag: Munich, Germany, 2014; pp. 127-145. ISBN 978-3-86581-723-5.

33. Findler, F.; Schönherr, N.; Lozano, R.; Reider, D.; Martinuzzi, A. The impacts of higher education institutions on sustainable development: A review and conceptualization. Int. J. Sustain. High. Educ. 2019, 20, 23-38. [CrossRef]

34. Blume, L.; Brenner, T.; Buenstorf, G. Universities and sustainable regional development: Introduction to the special issue. Rev. Reg. Res. 2017, 37, 103-109. [CrossRef]

35. Singer-Brodowski, M.; Schneidewind, U. Transformative Literacy: Understanding and shaping change processes in society. In Krisen und Transformationsszenarios: Frühkindpädagogik, Resilienz \& Weltaktionsprogramm; [Scenarios of Crisis and Transformation; Early Childhood Education, Resilience and the Global Action Program]; Sorgo, W., Ed.; Forum Umweltbildung: Vienna, Austria, 2014; pp. 131-140. ISBN 978-3-900-71776-6.

36. Wanner, M.; Schmitt, M.; Fischer, N.; Bernert, P. Transformative Innovation Lab Handbuch zur Ermöglichung Studentischer Reallabor-Projekte zur Förderung Transformativer und Transdisziplinärer Kompetenzen. Available online: www.transformativeinnovation-lab.de (accessed on 27 December 2020).

37. Wissenschaftliche Beirat der Bundesregierung Globale Umweltveränderungen (WBGU) [Academic Council of the Federal Government to address Global Environmental Change]. Hauptgutachten, Welt im Wandel, Gesellschaftsvertrag für Eine Große Transformation, 2nd ed.; [Report, A Changing World, Social Contract for a Major Transformation]; WBGU: Berlin, Germany, 2011; ISBN 978-3-936191-38-7.

38. Schneidewind, U.; Scheck, H. On the transformation of the energy sector-As seen from the perspective of transition research. In Smart Energy. Wandel zu Einem Nachhaltigen Energiesystem; [Smart Energy. Transformation to a Sustainable Energy System]; Servatisu, H.-G., Schneidewind, U., Rohlfing, D., Eds.; Springer: Berlin/Heidelberg, Germany, 2012; pp. 45-61. ISBN 978-3-642-21820-0.

39. Hochschule für Nachhaltige Entwicklung. Transferstrategie-Mission-Nachhaltigkeit. Available online: https://www.hnee.de/ de/Hochschule/Leitung/Strategiepapiere/Strategiepapiere-K5829.htm (accessed on 15 January 2021). 
40. Nölting, B.; Molitor, H.; Reimann, J.; Skroblin, J.H.; Dembski, N. Transfer for Sustainable Development at Higher Education Institutions-Untapped Potential for Education for Sustainable Development and for Societal Transformation. Sustainability 2020, 12, 2925. [CrossRef]

41. Hochschule für Nachhaltige Entwicklung. Grundsätze zur Nachhaltigen Entwicklung an der Hochschule für Nachhaltige Entwicklung Eberswalde. Available online: https://www.hnee.de/de/Hochschule/Leitung/Strategiepapiere/StrategiepapiereK5829.htm (accessed on 15 January 2021).

42. Ministerium für Wissenschaft, Forschung und Kultur (MWFK) [Ministry for Science, Research and Culture]. Transfer Strategy for Brandenburg-Improving Collaboration between Academia, Policymakers and Civil Society. 2017. Available online: https://mwfk.brandenburg.de/sixcms/media.php/9/MWFK_Transferstrategie_DIN_A4_eng1_2019-12-13.pdf (accessed on 10 December 2020).

43. Ministerium für Umwelt, Gesundheit und Verbraucherschutz des Landes Brandenburg (MUGV) [Ministry for Environment, Health and Consumer Protection for the Federal State of Brandenburg]. Naturally. Sustainable. Brandenburg. Sustainability Strategy for the Federal State of Brandenburg. Available online: https://mluk.brandenburg.de/cms/media.php/lbm1.a.3310.de/ nachhaltigkeitsstrategie_bb.pdf (accessed on 27 November 2020).

44. University for Sustainable Development. The Work of Academia in the Uckermark Region. Available online: https: / / www.hnee.de/de/Forschung/InnoSupport/Transfer/Prsenzstelle-Schwedt-\%7C-Uckermark/Prsenzstelle-Schwedt-\%7 CUckermark-E4284.htm (accessed on 13 December 2020).

45. Brandenburg University of Technology, Cottbus-Senftenberg (BTU). Transfer Strategy 2016. Available online: https:/ /www-docs. b-tu.de/wirtschaft/public/Transferstrategie_BTU.pdf (accessed on 10 December 2020).

46. Netzwerk n e.V. Zukunftsfähige Hochschulen Gestalten-Beispiele des Gelingens aus Lehre, Forschung, Betrieb, Governance und Transfer; Netzwerk n e.V.: Berlin, Germany, 2018; ISBN 978-3-981-96691-6.

47. University for Sustainable Development. Sustainability in Brandenburg Universities. Available online: https: / / nachhaltigkeitan-brandenburger-hochschulen.de/hochschulen/ (accessed on 13 December 2020).

48. Schneidewind, U.; Singer-Brodowski, M.; Augenstein, K.; Stelzer, F. Pledge for a Transformative Science: A Conceptual Framework. Wuppertal Paper 2016, 191, 2-29. [CrossRef]

49. Brundiers, K.; Barth, M.; Cebrián, G.; Cohen, M.; Diaz, L.; Doucette-Remington, S.; Dripps, W.; Habron, G.; Harré, N.; Jarchow, M.; et al. Key competencies in sustainability in higher education-Toward an agreed-upon reference framework. Sustain. Sci. 2020, 16, 1-17. [CrossRef]

50. de Haan, G. "Gestaltungskompetenz" as a skills concept for Education for Sustainable Development. In Kompetenzen der Bildung für Nachhaltige Entwicklung. Operationalisierung, Messung, Rahmenbedingungen, Befunde; [Skills Involved in Education for Sustainable Development. Operationalization, Measurement, Findings]; Bormann, I., de Haan, G., Eds.; VS Verlag für Sozialwissenschaften: Wiesbaden, Germany, 2008; pp. 23-44. ISBN 978-3-531-90832-8.

51. United Nations Educational, Scientific and Cultural Organization (UNESCO). Education for Sustainable Development Goals. Learning Objectives; UNESCO: Paris, France, 2017; ISBN 978-92-3-100209-0.

52. Rieckmann, M. The global perspective for Education for Sustainable Development. A European/Latin-American study on the key competencies required for thinking and acting in terms of a global society. In Reihe Umweltkommunikation; [Series on Environmental Communications]; Michelsen, G., Ed.; Berliner Wissenschaftsverlag: Berlin, Germany, 2010; ISBN 978-3-8305-1878-5.

53. Wiek, A.; Withycombe, L.; Redman, C.L. Key competencies in sustainability: A reference framework for academic program development. Sustain. Sci. 2011, 6, 203-218. [CrossRef]

54. Rieckmann, M. Education for Sustainable Development-Conceptual foundations and status of implementation. In Bildung für Nachhaltige Entwicklung in Pädagogischen Handlungsfeldern. Grundlagen, Verankerung und Methodik in Ausgewählten Lehr-LernKontexten; [Education for Sustainable Development in Educational Areas of Activity. Foundations, Anchoring and Methodology in Selected Teaching and Learning Contexts]; Schweer, M.K.W., Ed.; Verlag Peter Lang: Frankfurt am Main, Germany, 2016; pp. 11-32. ISBN 978-3-63-168128-2.

55. Barth, M.; Godemann, J.; Rieckmann, M.; Stoltenberg, U. Developing key competencies for sustainable development in higher education. Int. J. Sustain. High. Educ. 2007, 8, 416-430. [CrossRef]

56. David, C.K. Zukunft Mitgestalten. Bildung für Eine Nachhaltige Entwicklung-Didaktisches Konzept und Umsetzung in der Grundschule; [Co-Creating the Future. Education for Sustainable Development-Didactic concept and Implementation in the Elementary School]; Haupt: Bern, Switzerland, 2007; ISBN 978-3258072166.

57. Stoltenberg, U. Mensch und Wald. Theorie und Praxis Einer Bildung für Nachhaltige Entwicklung am Beispiel des Themenfeldes Wald; [People and the Forest. Theory and Practice of Education for Sustainable Development Using the Forest as an Example of a Suitable Topic]; Oekom Verlag: Munich, Germany, 2009; ISBN 978-3865811264.

58. Hafner, S.; Miosga, M. On the introduction: Regional transformation towards sustainability-Academia, the economy and civil society in dialog. In Regionale Nachhaltigkeitstransformation-Wissenschaft, Wirtschaft und Zivilgesellschaft im Dialog; [Regional Transformation towards sustainability-Academia, the Economy and Civil Society in Dialog]; Hafner, S., Miosga, M., Eds.; Oekom Verlag: Munich, Germany, 2014; pp. 11-57. ISBN 978-3-86581-723-5. 
59. Ebner, H.G.; Gellert, C. Service Learning as a competence-enhancing element of profile development. In Studentischer Kompetenzerwerb im Kontext von Hochschulsteuerung und Profilbildung; [The Acquisition of Competencies by Students in the Context of University Management and Profile, Development]; der Smitten, S., Ed.; HIS: Hannover, Germany, 2010; pp. 63-72. ISBN 978-3-930447-83-1.

60. Barth, M.; Adomßent, M.; Fischer, D.; Richter, S.; Rieckmann, M. Learning to change universities from within: A service-learning perspective on promoting sustainable consumption in higher education. J. Clean Prod. 2014, 62, 72-81. [CrossRef]

61. Schank, C.; Biberhofer, P.; Halberstadt, J.; Lorch, A. Service Learning as a competency-based form of teaching and learning. In Grenzen Überschreiten, Pluralismus Wagen-Perspektiven Sozioökonomischer Hochschullehre; [Pushing out the Boundaries, Daring to Try Pluralism-Perspectives for Socio-Economic University Teaching]; Fridrich, C., Hedtke, R., Ötsch, W., Eds.; VS Verlag für Sozialwissenschaften: Wiesbaden, Germany, 2020; Volume 1, pp. 217-239. ISBN 978-3-658-29642-1.

62. Flohr, M.; Markus, L. Sufficiency in Universities. Available online: https://www.researchgate.net/publication/342991904_ Suffizienz_anHochschulen_im_landlichen_Raum (accessed on 13 December 2020).

63. Netzwerk n e.V.; VCD Verkehrsclub Deutschland e.V. Sustainable Mobility in Universities. Available online: https: / / diy.vcd.org/fileadmin/user_upload/DIY/Broschuere_Mobilitaet_Hochschule/Good_Practice-Sammlung_Nachhaltige_ Mobilitaet_an_Hochschulen_online_kl.pdf (accessed on 13 December 2020).

64. Singer-Brodowski, M. Students' Competency Development in the Context of Self-Organized and Project-Oriented Sustainability Seminars: Research at the Interface between Self-Description and Real-Life Action. In Routledge Handbook of Higher Education for Sustainable Development; Barth, M., Michelsen, G., Rieckmann, M., Thomas, I., Eds.; Routledge: London, UK, 2016 ; pp. 411-420. ISBN 9781138597549.

65. Reimann, J. Nachhaltigkeitstransfer an Hochschulen und der Beitrag für eine Nachhaltige Regionalentwicklung-Die Rolle von Studierenden in Projektarbeiten zur Regionalentwicklung; [Sustainability Transfer at Universities and the Contribution Made to Sustainable Regional Development-The Role of Students in Project Work in the Field of Regional Development]. Master's Thesis, Eberswalde University for Sustainable Development, Eberswalde, Germany, 2019.

66. Office for Statistics for Berlin-Brandenburg. Students at Universities in the Federal State of Brandenburg in the 2018/2019 Winter Semester. Part 1: Overview. Available online: https://www.statistik-berlin-brandenburg.de/publikationen/stat_berichte/2019 /SB_B03-02-00_2018j01_BB.pdf (accessed on 26 March 2020).

67. Office for Statistics for Berlin-Brandenburg. Staff at Universities in the Federal State of Brandenburg. 2018. Available online: https:/ / www.statistik-berlin-brandenburg.de/publikationen/stat_berichte/2019/SB_B03-04-00_2018j01_BB.pdf (accessed on 26 March 2020).

68. Bolden, R.; Moscarlola, J. Bridging the Quantitative-Qualitative Divide. The Lexical Approach to Textual Data Analysis. Soc. Sci. Comput. Rev. 2000, 18, 450-460. [CrossRef]

69. Tilbury, D.; Janousek, S. Development of a National Approach to Monitoring, Assessment and Reporting on the Decade of Education for Sustainable Development: Summarising Documented Experiences on the Development of ESD Indicators and Networking with Expert Groups on ESD Indicators; Australian Research Institute of Education for Sustainability and Australian Government Department of the Environment, Water, Heritage and the Arts: Sydney, Australia, 2006; ISBN 978-1-741-38214-3.

70. Döbert, H.; Weishaupt, H. Bildungsmonitoring. In Schul und Unterrichtsreform Durch Ergebnisorientierte Steuerung: Empirische Befunde und Forschungsmethodische Implikationen; Wacker, A., Maier, U., Wissinger, J., Eds.; VS Verlag für Sozialwissenschaften: Wiesbaden, Germany, 2012; pp. 155-173. ISBN 978-3-531-94183-7.

71. Michelsen, G.; Adomßent, M.; Bormann, I.; Burandt, S.; Fischbach, R. Indikatoren der Bildung für Nachhaltige Entwicklung-Ein Werkstattbericht [Education for Sustainable Development Indicators-A Workshop Report]. Available online: https: / /www.bneportal.de/publikationen/1172/downloads/DUK\%20-\%20Indikatoren\%20BNE.pdf (accessed on 25 April 2020).

72. United Nations Economic Commission for Europe (UNECE). Indicators for Education for Sustainable Development: Progress Report on the Work of the Expert Group. Available online: https:/ /digitallibrary.un.org/record/580720?ln=en (accessed on 25 April 2020).

73. United Nations Economic Commission for Europe (UNECE). Report of the UNECE Steering Committee on Education for Sustainable Development on Its Third Meeting. Available online: http:/ /staging2.unece.org.net4all.ch/fileadmin/DAM/env/ documents /2008/ece/cep/ac.13/ece.cep.ac.13.2008.2.e.pdf (accessed on 18 January 2021).

74. United Nations Educational, Scientific and Cultural Organization (UNESCO). UNESCO Roadmap for Implementing the Global Action Programme on Education for Sustainable Development. Available online: https://sustainabledevelopment.un.org/ content/documents/1674unescoroadmap.pdf (accessed on 18 January 2021).

75. University of Potsdam. Study and Examination Regulations. Available online: https://www.uni-potsdam.de/de/studium/ konkret/rechtsgrundlagen/studienordnungen.html (accessed on 29 March 2020).

76. Brandenburg University of Technology. Cottbus-Senftenberg. Examination and Study Regulations. Available online: https: //www.b-tu.de/studierende/studierendenservice/ordnungen-und-formulare/pruefungs-und-studienordnungen (accessed on 29 March 2020).

77. Viadrina European University, Frankfurt (Oder). Current Sets of Regulations for the Study Programs. Available online: https:// www.europa-uni.de/de/struktur/verwaltung/dezernat_2/amtliche_bekanntmachungen/gueltige-ordnungen/index.html (accessed on 29 March 2020). 
78. Potsdam University of Applied Sciences. Study and Examination Regulations. Available online: https:/ /www.fh-potsdam.de/ informieren/profil/amtl-bekanntmachungen/studien-und-pruefungsordnungen/ (accessed on 29 March 2020).

79. KONRAD WOLF Film University of Babelsberg. Regulations \& Statutes. Available online: https://www.filmuniversitaet.de/ studium/studienorganisation/ordnungen-satzungen/ (accessed on 29 March 2020).

80. Eberswalde University for Sustainable Development. Enrolment Regulations, Study and Examination Regulations. Available online: https:/ /hnee.de/de/Studium/Infos-zum-Studium/Studien-Prfungsordnungen/Immatrikulations-Studien-undPrfungsordnungen-K714.htm (accessed on 29 March 2020).

81. Brandenburg University of Applied Sciences. Study and Examination Regulations. Available online: https://www.th-brandenburg. de/studium/pruefungen-und-termine/ordnungen/studien-und-pruefungsordnungen/ (accessed on 29 March 2020).

82. Technical University of Applied Sciences, Wildau. Study Programs A-Z. A Full Overview of all the Courses of Study at TH Wildau. Available online: https:/ / www.th-wildau.de/studieren-weiterbilden/studiengaenge/ (accessed on 29 March 2020).

83. Bowen, G.A. Document Analysis as a Qualitative Research Method. Qual. Res. J. 2009, 9, 27-40. [CrossRef]

84. Gläser, J.; Laudel, G. Expert Interviews and Qualitative Content Analysis as an Instrument for Reconstrictive Studies, 4th ed.; [Experteninterviews und Qualitative Inhaltsanalyse. als Instrument Rekonstruierender Untersuchungen]; Verlag für Sozialwissenschaften: Wiesbaden, Germany, 2010; ISBN 978-3-531-17238-5.

85. Waltner, E.-M.; Rieß, W.; Brock, A. Development of an ESD Indicator for Teacher Training and the National Monitoring for ESD Implementation in Germany. Sustainability 2018, 10, 2508. [CrossRef]

86. World Commission on Environment and Development (WCED). Our Common Future. Available online: https:// sustainabledevelopment.un.org/content/documents/5987our-common-future.pdf (accessed on 13 December 2020).

87. Riekmann, M. Key Themes in Education for Sustainable Development. In Issues and Trends in Education for Sustainable Development; Leicht, A., Heiss, J., Byun, W.J., Eds.; UNESCO: Paris, France, 2018; pp. 61-84. ISBN 978-92-3-100244-1.

88. Sedlacek, S. The role of universities in fostering sustainable development at the regional level. J. Clean Prod. 2013, 48, 74-84. [CrossRef]

89. Higher Education Compass Study Programs. 2020. Available online: https://www.hochschulkompass.de/studium/ studiengangsuche/erweiterte-studiengangsuche.html (accessed on 13 December 2020).

90. Toepfer Stiftung gGmbH. The Development of Teaching as a Task within the Culture of the Various Disciplines. Available online: https: / lehrehochn.de/programme/\#fachprogramm (accessed on 13 December 2020).

91. Leuphana University of Lüneburg. LENA-Teacher Training for Sustainable Development. Available online: https: / / netzwerklena.files.wordpress.com/2020/07/lena_publikation_2017.pdf (accessed on 13 December 2020).

92. Valderrama-Hernández, R.; Sánchez-Carracedo, F.; Alcántara Rubio, L.; Limón-Domínguez, D. Methodology to Analyze the Effectiveness of ESD in a Higher Degree in Education. A Case Study. Sustainability 2020, 12, 222. [CrossRef]

93. Wolff, L.-A.; Ehrström, P. Social Sustainability and Transformation in Higher Educational Settings: A Utopia or Possibility? Sustainability 2020, 12, 4176. [CrossRef]

94. Weiss, M.; Barth, M.; Wiek, A.; von Wehrden, H. Drivers and Barriers of Implementing Sustainability Curricula in Higher Education-Assumptions and Evidence. High. Educ. Stud. 2021, 11, 42-64. [CrossRef] 